This item was submitted to Loughborough's Research Repository by the author.

Items in Figshare are protected by copyright, with all rights reserved, unless otherwise indicated.

\title{
Fiscal policy with banks and financial frictions
}

PLEASE CITE THE PUBLISHED VERSION

https://doi.org/10.1016/j.jfs.2017.10.010

PUBLISHER

(c) Elsevier

VERSION

AM (Accepted Manuscript)

PUBLISHER STATEMENT

This work is made available according to the conditions of the Creative Commons Attribution-NonCommercialNoDerivatives 4.0 International (CC BY-NC-ND 4.0) licence. Full details of this licence are available at: https://creativecommons.org/licenses/by-nc-nd/4.0/

\section{LICENCE}

CC BY-NC-ND 4.0

\section{REPOSITORY RECORD}

Asimakopoulos, Panagiotis, and Stylianos Asimakopoulos. 2019. "Fiscal Policy with Banks and Financial Frictions". figshare. https://hdl.handle.net/2134/27458. 


\title{
Fiscal policy with banks and financial frictions*
}

\author{
Panagiotis Asimakopoulos $^{\dagger} \quad$ Stylianos Asimakopoulos ${ }^{\ddagger}$
}

\begin{abstract}
We assess the role of banks to the transmission of optimal and exogenous changes in fiscal policy to the economy. We built-up a dynamic stochastic general equilibrium model with patient and impatient agents, banks and a government to find that banks and their associated capital-adequacy constraint mitigate the negative spill-over effects to the economy from higher taxes. Specifically, we confirm that labour income tax is the most distortionary fiscal instrument. The optimal choice of a housing tax is the most favorable funding source to a temporary increase in public spending. The combination of housing and labour taxes is the most preferred tax bundle to be optimally chosen under negative output shocks. Moreover, a permanent increase in housing tax is beneficial if it is welfare enhancing and the existence of banks benefits mainly impatient households under permanently higher consumption taxes. Finally, these results remain robust to various robustness checks.
\end{abstract}

Keywords: optimal fiscal policy, policy reforms, banks, financial frictions JEL Classification: E21, E44, E47, E62, H24

*We would like to thank the editor, Iftekhar Hasan, one anonymous referee, Mirco Balatti, Emmanuel Tsiritakis, Huainan Zhao, participants at the FEBS Conference 2015, IMAEF Conference 2016 and EFMA Conference 2017 for helpful comments and suggestions.

${ }^{\dagger}$ Loughborough University, School of Business and Economics; email: p.asimakopoulos@lboro.ac.uk

¥University of Bath, Department of Economics; email: s.asimakopoulos@bath.ac.uk (corresponding author) 


\section{Introduction}

This paper introduces a fiscal sector in a real business cycle model with banks and financial frictions. The importance of banks in macroeconomic modelling has been well documented in the literature (see e.g. Brunnermeier and Sannikov, 2014, Kollman et al., 2011, and Meh and Moran, 2010). However, the role of banks and the associated borrowing constraints, faced by households and entrepreneurs, under optimal fiscal policy and various fiscal policy reforms has not drawn the required attention in the literature.

This is specifically relevant under the current economic climate where fiscal policy is being used as the main source for enhancing economic growth and the role of banks is re-evaluated. Moreover, it is crucial to examine under this environment the role of the various financial frictions in the economy with housing being the key source of collateral. Housing is the key asset for the vast majority of households in the U.S with $65 \%$ of the population owning a house. ${ }^{1}$ In addition, the value of housing is even higher than that of gross domestic product (GDP). As a result, housing affects significantly the financial constraints of agents in the economy (see also Alpanda and Zubairy, 2016 and references therein) and it is even more pronounced under the presence of banks (Iacoviello, 2015).

Moreover, the recent financial and subsequent sovereign debt crisis shifted the attention of policy-makers to fiscal policy, where many developed countries increased their level of public spending. In the United States, for example, a new fiscal package was introduced to stimulate demand, mainly through higher spending, according to "The 2015 Long-Term Budget Outlook" of the Congressional Budget Office. This policy increased deficit at about $\$ 5.6$ trillion over the 2008-2012 period and debt to output ratio reached the level of $74 \%$ in $2015 .^{2}$ As a consequence, it is crucial to understand and identify the macroeconomic implications of changes in fiscal policy instruments and particularly tax rates that are used to finance the increased level of debt.

The optimal reaction of fiscal policy will be assessed under the assumption that the government cannot issue debt to respond to exogenous shocks, following Angelopoulos et al. (2017). This restriction is particularly relevant under the current economic climate where many advanced economies are restricted from using debt as a shock absorbing mechanism.

Taking the above into consideration, this paper investigates how optimal fiscal policy and various fiscal policy reforms (i.e. exogenous changes/ increases in the tax structure) might affect the economy in terms of output

\footnotetext{
${ }^{1}$ Data on Homeownership Rates for the US and Regions are for the period 1965-2015, from Table 14 of the U.S. Census Bureau.

${ }^{2}$ This is the highest level of debt for the US in the post WWII period.
} 
and welfare under the presence of banks and financially constrained agents, using a dynamic stochastic general equilibrium (DSGE) model. Therefore, we want to fill the gap in the literature that examines the role of banks and fiscal policy separately. Our ultimate aim is to examine how the existence of banks and financial frictions affect the economy: i) when the government can optimally react to various negative shocks; and ii) when various fiscal policy reforms are implemented to fund the increased level of spending.

Therefore, this paper also contributes to the related literature by assessing the optimal fiscal policy under macroeconomic and financial shocks. The analysis of optimal fiscal policy will be focused on two types of policy experiments. First, we are going to allow for one distorting tax at a time to be optimally chosen under each shock. Comparing this with the case where tax rates are being kept fixed (benchmark case) will help us understand the transmission mechanisms of each tax instrument. Second, we are going to allow for a combination of the policy instruments to be optimally chosen under each shock. For both policy experiments we will also assess the spillover effects to aggregate output and consumption and identify the channels through which fiscal policy affects the economy and welfare. ${ }^{3}$

Our model follows Kiyotaki and Moore (1997) and Iacoviello (2005) work by introducing banks and implementing financially constrained households and entrepreneurs with housing as a collateral. The objective is to assess the interaction of banks as financial intermediaries with a government and their associated effects on inequality and welfare.

Alpanda and Zubairy (2016), in a similar approach to our work, extend Iacoviello (2005) earlier work by introducing a fiscal sector and renters to the economy and by allowing housing to be endogenously determined. We also allow for housing to be endogenously determined and we also introduce a rich fiscal sector but we do not introduce renters and we deviate from nominal rigidities. ${ }^{4}$ In addition, Alpanda and Zubairy (2016) did not include a banking sector, as in Iacoviello (2015) and our paper, and their focus was on the housing-related tax changes and not on the role of banks to the propagation mechanism of various fiscal policy reforms to the economy, as in our paper.

\footnotetext{
${ }^{3}$ Our paper is also related to the optimal taxation literature that examines the long run properties of optimal capital and labour income taxes, see e.g. Chari et al., 1994 and Angelopoulos et al., 2015. However, our focus is to assess the role of banks under various fiscal policy experiments and not the steady state outcome of the optimal tax rates. Nevertheless, our results are comparable and in line with this literature as well, but we choose not to focus on this aspect.

${ }^{4}$ Introducing renters in our model would be very interesting but we leave that for future research. Alpanda and Zubairy (2016) introduced renters because they examined housing specific tax polixy reforms.
} 
Finally, we also perform an optimal fiscal policy analysis.

Gertler and Karadi (2011) and Gertler and Kiyotaki (2010), among others, have established the importance of banks as financial intermediaries, applying a balanced sheet constraint. Iacoviello (2005) was the first to introduce a housing sector and monetary policy to assess the propagation mechanism of various shocks to the economy. Later on Iacoviello (2015) extended his work introducing banks as financial intermediaries in a Real Business Cycle model, without monetary and fiscal policy, to assess the importance of various financial shocks in the economy.

On the fiscal policy aspect, most of the related papers apply an overlapping generations model and examine the effects of various real estate related taxes (i.e. property tax, mortgage interest tax etc.) on home owners and renters, i.e. Gervais (2002) and Chambers et al. (2009). More recently, Alpanda and Zubairy (2016) implemented a dynamic general equilibrium model to examine housing tax related policies.

In addition, Fernandez-Villaverde (2010) also examined the effects on output from various temporary fiscal shocks. However, he assumes that debt will always adjust to finance the increased spending or the reduction in taxes and he also abstracts from any optimal fiscal policy discussion. Therefore, our paper can be seen as an extension of Fernandez-Villaverde (2010) work.

Our paper is also related to another strand of literature that examines monetary and fiscal policy interactions in the presence of financial frictions. For example, Cui (2016) examines the monetary-fiscal interactions with liquidity frictions using a simple fiscal rule for stabilization reasons with one fiscal instrument and allow for debt to be optimally determined. In contrast, we only focus on fiscal policy and we allow for transfers to follow a fiscal rule, choosing optimally the level of taxes and keeping debt fixed (due to the assumed balanced budget constraint). ${ }^{5}$ In addition, Gomes and Seoane (2017) focus on a monetary-fiscal policy mix in the presence of financial frictions over the recent crisis but without optimal fiscal policy analysis. As in our paper, they also assume that debt is the residual instrument that balances the government budget constraint under an exogenous fiscal policy. However, they only use a lump-sum tax which follows an autoregressive process, whereas we have several fiscal instruments.

Therefore, our paper contributes to this literature by focusing on fiscal policy in the presence of banks and financial frictions implementing various fiscal policy responses and an optimal fiscal policy analysis.

\footnotetext{
${ }^{5}$ Of course there are many ways to setup the model but we believe that under the current economic climate where governments are restricted from issuing more debt, a balanced budget restriction (where debt is fixed) is not very unreasonable.
} 
To the best of our knowledge, there is no work on the propagation effects of (optimal) fiscal policy in a framework with banks as financial intermediaries, patient-impatient households and financial frictions. Moreover, the assessment of optimal fiscal policy under the current setup is novel.

We introduce a fiscal sector in a dynamic stochastic general equilibrium model with banks, two types of households (patient and impatient) and entrepreneurs so as to be able to assess the various, and possibly asymmetric, effects of fiscal policy on different agents in the economy. Specifically we follow a standard calibration approach so as to match the key U.S. data over the past three decades and we initially assess the effects of optimal fiscal policy under uncertainty to the economy. ${ }^{6}$ We also assess how various permanent fiscal policy reforms affect the economy and welfare of each agent, motivated from the current economic climate that suggests the need to fund the high level of debt and higher public spending via higher taxes. ${ }^{7}$

The main questions we would like to answer are: 1) What is the optimal fiscal policy recommendation under uncertainty and what is the role of banks? 2) How the existence of banks affects the propagation of higher government spending and the transmission of various fiscal policy reforms to the economy? 3) What are the welfare implications? 4) How a structural change in the financial frictions can affect the transmission of the shocks to the economy?

An overview of the main findings is the following: i) The existence of banks can mitigate the negative spillover effects to the economy from higher taxes under both optimal fiscal policy and various fiscal policy reforms; ii) Optimal fiscal policy experiments under uncertainty confirm that labour taxes are the most distortionary fiscal policy instrument; iii) When housing tax is used optimally as a source of financing temporary higher government spending it may lead to higher level of output in the short run; iv) The optimal combination of labour and housing taxes is the most preferred tax bundle; v) Permanently higher housing taxes and government spending affect mostly borrowers' welfare; vi) Entrepreneurs are mainly better off following an increase in the consumption tax, due to the income redistribution via transfers; vii) A decrease in the net worth of loan suppliers amplifies the negative spillover effects to the economy; and viii) Our main results are robust in changes to the financial frictions specification.

\footnotetext{
${ }^{6}$ Uncertainty in our model takes the form of temporary negative output shocks, such as: negative total factor productivity shock, negative housing demand shock, positive loan-to-value ratio shock and finally positive government spending shock.

${ }^{7}$ Under fiscal policy reforms we examine the economic and welfare implications from a permanent increase in government spending, housing tax, labour tax and consumption tax under the presence of banks.
} 
The remainder of the paper is organized as follow. Section 2 presents and describes the model. Section 3 outlines the calibration. Section 4 presents the results under exogenous and optimal fiscal policy. Section 5 illustrates the results of permanent fiscal policy reforms along with various robustness checks. Finally, Section 6 draws the conclusions.

\section{Model}

We employ a real business cycle model with two types of households (patient and impatient), entrepreneurs, banks and a government. Patient households are assumed to be the savers and owners of housing. They also work, consume, make one-period deposits to banks and have access to one-period government bonds. Impatient households consume, work, own housing and have access to one-period bank loans. The impatient households are under a borrowing constraint determined by the value of their housing which is used as collateral (i.e. Kiyotaki and Moore (1997) and Iacoviello (2015)). Entrepreneurs hire workers from the two households, accumulate real estate and borrow from banks. They are also under a borrowing constraint which is determined by the value of their collateral and the wage rates paid in advance, as in Neumeyer and Perri (2005). Banks borrow from patient households, in the form of deposits, and provide one-period loans to impatient households and entrepreneurs. Finally, government spending is financed via debt, lump-sum transfers, consumption, labour and housing taxes.

\subsection{Patient households}

Patient households have the following objective function:

$$
\max E_{0} \sum_{t=0}^{\infty} \beta_{P}^{t}\left[\log C_{P, t}+j A_{t}^{J} \log H_{P, t}+\eta \log \left(1-N_{P, t}\right)\right]
$$

where $E_{0}$ is the conditional expectations operator at period $0 ; 0<\beta_{P}^{t}<1$ is the time discount factor; $C_{P, t}$ and $N_{P, t}$ are private consumption and working hours respectively at period $t$; and $H_{P, t}$ is housing at period $t$. $A_{t}^{J}$ denotes a demand shock to housing. The parameters $j$ and $\eta$ capture the weights of real estate and leisure on the welfare respectively.

The demand shock, $A_{t}^{J}$, is assumed to follow an exogenous stochastic $\mathrm{AR}(1)$ process:

$$
\log \left(A_{t+1}^{J}\right)=\left(1-\rho_{A^{J}}\right) \log \left(A^{J}\right)+\rho_{A^{J}} \log \left(A_{t}^{J}\right)+\varepsilon_{t}^{A^{J}}
$$


where $\varepsilon_{t}^{A^{J}}$ is independently and identically distributed Gaussian random variable with zero mean and standard deviation given by $\sigma_{A^{J}}$.

The representative patient household chooses consumption, labour, housing, bonds and deposits, $C_{P, t}, N_{P, t}, H_{P, t}, B_{t}$ and $D_{t}$ respectively, so as to maximize equation (1) subject to the following budget constraint:

$$
\begin{aligned}
& \left(1+\tau_{t}^{C}\right) C_{P, t}+D_{t}+B_{t}+q_{t}\left(H_{P, t}-\left(1-\tau_{t}^{H}\right) H_{P, t-1}\right) \\
& =R_{P, t-1} D_{t-1}+R_{B, t-1} B_{t-1}+\left(1-\tau_{t}^{W}\right) W_{P, t} N_{P, t}+t r_{t}
\end{aligned}
$$

where we assume that patient households have deposits, $D_{t}$, at the bank earning a gross return $R_{P, t}$. It is further assumed that patient households have access to government bonds, $B_{t}$, with a gross return $R_{B, t}$. In addition, $q_{t}$ denotes the relative price of housing and $\tau_{t}^{H}$ is the property tax rate on housing. $W_{P, t}$ is the wage rate and $\tau_{t}^{W}$ is the labour tax rate. Finally, patient households receive lump-sum transfers from the government, $t r_{t}$, and they are subject to a consumption tax, $\tau_{t}^{C}$.

\subsection{Impatient households}

Impatient households have the following objective function:

$$
\max E_{0} \sum_{t=0}^{\infty} \beta_{I}^{t}\left[\log C_{I, t}+j A_{t}^{J} \log H_{I, t}+\eta \log \left(1-N_{I, t}\right)\right]
$$

where $0<\beta_{I}^{t}<1$ is the time discount factor with $0<\beta_{I}^{t}<\beta_{P}^{t} ; C_{I, t}$ and $N_{I, t}$ are private consumption and working hours respectively at period $t$; and $H_{P, t}$ is housing at period $t$.

The representative impatient household chooses consumption, labour, housing and loans, $C_{I, t}, N_{I, t}, H_{I, t}$ and $L_{I, t}$, respectively, so as to maximize equation (4) subject to the following budget constraint:

$$
\begin{aligned}
& \left(1+\tau_{t}^{C}\right) C_{I, t}+R_{I, t-1} L_{I, t-1}+q_{t}\left(H_{I, t}-\left(1-\tau_{t}^{H}\right) H_{I, t-1}\right) \\
& =L_{I, t}+\left(1-\tau_{t}^{W}\right) W_{I, t} N_{I, t}+t r_{t}
\end{aligned}
$$

where we assume that impatient households receive bank loans, $L_{I, t}$, with gross interest rate $R_{I, t}$. It is further assumed that impatient households do not have access to government bonds and they are subject to a property tax rate on housing $\tau_{t}^{H}$. Their wage rate is defined as, $W_{P, t}$, and it is subject to a labour tax rate, $\tau_{t}^{W}$. Impatient households also receive lump-sum transfers from the government, $t r_{t}$ and are subject to a consumption tax, $\tau_{t}^{C}$. 
Impatient households are assumed to be constraint on the amount they are able to borrow given their stock of real estate:

$$
L_{I, t} \leq \rho_{I} L_{I, t-1}+\left(1-\rho_{I}\right) A_{t}^{M} m_{I} E_{t}\left(\frac{q_{t+1}}{R_{I, t}} H_{I, t}\right)
$$

where $\rho_{I}$ captures the inertia in the adjustment of the borrowing constraint over time and the parameter $m_{I}$ determines the loan-to-value ratio in terms of the real estate used as a collateral. ${ }^{8}$ In addition, $A_{t}^{M}$ captures an exogenous shock on the loan-to-value ratio and it follows an $\mathrm{AR}(1)$ process:

$$
\log \left(A_{t+1}^{M}\right)=\left(1-\rho_{A^{M}}\right) \log \left(A^{M}\right)+\rho_{A^{M}} \log \left(A_{t}^{M}\right)+\varepsilon_{t}^{A^{M}}
$$

where $\varepsilon_{t}^{A^{M}}$ is independently and identically distributed Gaussian random variable with zero mean and standard deviation given by $\sigma_{A^{M}}$.

\subsection{Entrepreneurs}

Entrepreneurs behave similarly to impatient households with the following objective function:

$$
\max E_{0} \sum_{t=0}^{\infty} \beta_{E}^{t}\left[\log C_{E, t}\right]
$$

where we assume that $0<\beta_{E}\left(1-\left(\left(1-\beta_{B}\right) \rho_{B}+\left(1-\rho_{B}\right) \gamma\right) \frac{1-\beta_{B} R_{P}}{1-\beta_{B} \rho_{B}}\right)<$ $\beta_{B} \cdot{ }^{9}$

The representative entrepreneur chooses consumption, $C_{E, t}$, housing, $H_{E, t}$ and loans $L_{E, t}$, so as to maximize equation (8) subject to the following budget constraint:

$$
\begin{aligned}
& \left(1+\tau_{t}^{C}\right) C_{E, t}+R_{E, t} L_{E, t-1}+q_{t} H_{E, t}+W_{P, t} N_{P, t}+W_{I, t} N_{I, t} \\
& =Y_{t}+L_{E, t}+q_{t}\left(1-\tau_{t}^{H}\right) H_{E, t-1}+t r_{t}
\end{aligned}
$$

where $L_{E, t}$ denotes the bank loans with gross interest rate $R_{E, t}$. It is further assumed that entrepreneurs are subject to a property tax rate on housing $\tau_{t}^{H}$, receive lump-sum transfers from the government, $t r_{t}$, and they are subject to a consumption tax, $\tau_{t}^{C}$.

\footnotetext{
${ }^{8}$ Following, Iacoviello (2015) the borrowing constraint is binding around the steady state if the time discount factor of impatient households satisfies the following: $\beta_{I}<$ $\left(1-\left(\left(1-\beta_{B}\right) \rho_{B}+\left(1-\rho_{B}\right) \gamma\right) \frac{1-\beta_{B} R_{P}}{1-\beta_{B} \rho_{B}}\right) \beta_{B}$

${ }^{9}$ See Iacoviello (2015) for more details on this restriction.
} 
Furthermore, entrepreneurs are subject to the following borrowing constraint:

$$
L_{E, t} \leq \rho_{E} L_{E, t-1}+\left(1-\rho_{E}\right) A_{t}^{M}\left[\begin{array}{c}
m_{E H} E_{t}\left(\frac{q_{t+1}}{R_{E, t+1}} H_{E, t}\right) \\
-m_{E N}\left(W_{P, t} N_{P, t}+W_{I, t} N_{I, t}\right)
\end{array}\right]
$$

where, as in the impatient households, $\rho_{E}$ captures the inertia in the adjustment of the borrowing constraint over time. The parameter $m_{E H}$ determines the loan-to-value ratio in terms of their real estate stock used as collateral. The term $m_{E N}$ captures the assumption that a fraction of the wage payment needs to be made in advance, following Iacoviello (2015) and Neumeyer and Perri (2005).

Entrepreneurs combine real estate and labour supply from patient and impatient households to produce the final output given by:

$$
Y_{t}=A_{Z, t}\left(H_{E, t-1}\right)^{v}\left(N_{P, t}\right)^{(1-v)(1-\sigma)}\left(N_{I, t}\right)^{(1-v) \sigma}
$$

where $v$ determines the share of entrepreneur's real estate on the production process and $\sigma$ determines the relative share of impatient labour supply in the production.

Total factor productivity, $A_{Z, t}$, is assumed to follow a stochastic exogenous $\operatorname{AR}(1)$ process:

$$
\log \left(A_{Z, t+1}\right)=\left(1-\rho_{A_{Z}}\right) \log \left(A_{Z}\right)+\rho_{A_{Z}} \log \left(A_{Z, t}\right)+\varepsilon_{t}^{A_{Z}}
$$

where $\varepsilon_{t}^{A_{Z}}$ is independently and identically distributed Gaussian random variable with zero mean and standard deviation given by $\sigma_{A_{Z}}$.

\subsection{Banks}

Banks have the following objective function:

$$
\max E_{0} \sum_{t=0}^{\infty} \beta_{B}^{t} \log C_{B, t}
$$

where, following Iacoviello (2015) we set $0<\beta_{B}<\beta_{P}$.

The representative bank chooses consumption, $C_{B, t}$, deposits, $D_{t}$, and the loans given to impatient households and entrepreneurs, $L_{I, t}$ and $L_{E, t}$ respectively, so as to maximize (13) subject to the following budget constraint:

$$
\begin{aligned}
& \left(1+\tau_{t}^{C}\right) C_{B, t}+R_{P, t-1} D_{t-1}+L_{E, t}+L_{I, t} \\
& =D_{t}+R_{E, t} L_{E, t}+R_{I, t-1} L_{I, t-1}+t r_{t}
\end{aligned}
$$


where $\tau_{t}^{C}$ is the consumption tax rate and $t r_{t}$ are the lump-sum transfers.

The bank is also subject to a capital adequacy constraint:

$$
L_{t}-D_{t} \geq \rho_{B}\left(L_{t-1}-D_{t-1}\right)+(1-\gamma)\left(1-\rho_{B}\right) L_{t}
$$

where it states that bank equity must exceed a fraction of bank assets. The parameter $\gamma$ captures the liabilities to asset ratio and the parameter $\rho_{D}$ captures the inertia in the capital adequacy constraint.

\subsection{The government}

The government's budget constraint is given by:

$$
\begin{aligned}
& \tau_{t}^{H}\left(H_{P, t-1}+H_{I, t-1}+H_{E, t-1}\right)+\tau_{t}^{W}\left(W_{P, t} N_{P, t}+W_{I, t} N_{I, t}\right)+ \\
& \tau_{t}^{C}\left(C_{P, t}+C_{I, t}+C_{E, t}+C_{B, t}\right)=G_{t}+R_{B, t-1} B_{t-1}-B_{t}+t r_{t}
\end{aligned}
$$

where $G_{t}$ denotes public spending.

Following Leeper et al. (2010) and Alpanda and Zubairy (2016) we allow for transfers to adjust with government debt so as for the government not to run a Ponzi scheme.

$$
\hat{t r}_{t}=-\gamma_{Y} \hat{Y}_{t}-\gamma_{B} \hat{B}_{t-1}
$$

where the hatted-variables, $\hat{x}$, denote the percent deviations from the steadystate of the respective variable The parameters $\gamma_{Y}$ and $\gamma_{B}$ are the reaction coefficients of the percentage change of transfers to the percentage deviation of current output and lagged debt. ${ }^{10}$

We further assume that spending follow an exogenous $\mathrm{AR}(1)$ process:

$$
\log \left(G_{t+1}\right)=\rho_{g} \log \left(G_{t}\right)+\left(1-\rho_{g}\right) \log (G)+\varepsilon_{t}^{G}
$$

where $G$ is the level of government spending at the steady-state and $\varepsilon_{t}^{G}$ is independently and identically distributed Gaussian random variable with zero mean and standard deviation given by $\sigma_{G}$.

\subsection{Market clearing conditions}

The market clearing conditions for private consumption and housing are given by:

$$
C_{P, t}+C_{I, t}+C_{E, t}+C_{B, t}=C_{t}
$$

\footnotetext{
${ }^{10}$ In our experiments we want to have transfers to savers and borrowers only. Therefore, transfers to banks are assumed to be zero throughout the paper, apart from a robustness check towards the end of the paper. However, they do not significantly afffect our results if they follow a similar pattern witht the rest of the transfers. These results are available upon request.
} 


$$
H_{P, t}+H_{I, t}+H_{E, t}=1
$$

To solve the model dynamics we use Dynare and we estimate our model using a non-linear version of the system of equations and under the assumption that all the constraints outlined above are binding.

\subsection{Decentralized competitive equilibrium}

Given initial levels of the assets, $H_{j, 0}, B_{0}$, the initial deposits of patient households $D_{0}$, the stationary stochastic processes for technology, government spending, loan-to-value ratio and housing demand $\left\{A_{Z, t}, G_{t}, A_{t}^{M}, A_{t}^{J}\right\}_{t=0}^{\infty}$ for $j=P, I, E$, the decentralized competitive equilibrium system of equations is characterized by a sequence of allocations $\left\{C_{P, t}, C_{I, t}, C_{E, t}, C_{B, t}, H_{P, t}, H_{I, t}\right.$, $\left.H_{E, t}, N_{P, t}, N_{I, t}, B_{t}, D_{t}, L_{I, t}, L_{E, t}\right\}_{t=0}^{\infty}$ and prices $\left\{W_{P, t}, W_{I, t}, q_{t}, R_{P, t}, R_{B, t}\right.$, $\left.R_{I, t}, R_{E, t}\right\}_{t=0}^{\infty}$ such that: (i) both types of households, entrepreneurs and banks maximize their welfare, taking prices as given; (ii) the government budget constraint is satisfied in each period and (iii) all markets clear. ${ }^{11}$

\section{Calibration}

For our calibration we follow the papers of Iacoviello (2015) and Leeper et al. (2010), along with annual U.S. fiscal data obtained from Bureau of Economic Analysis (BEA) and Federal Reserve Economic Data (FRED) from St. Louis Federal Reserve Bank. The calibrated parameters are summarized in Table 1 .

The welfare parameters, time preferences and the parameters regarding the financial frictions are set as in Iacoviello (2015). Moreover, the consumption tax and the reaction coefficients of the fiscal rules are set as in Leeper

\footnotetext{
${ }^{11}$ The first order conditions of our model are presented and briefly discussed in the appendix.
} 
et al. (2010). ${ }^{12}$

Table 1: Model parameters

\begin{tabular}{ccll}
\hline \hline Parameter & Value & \multicolumn{1}{c}{ Definition } & \multicolumn{1}{c}{ Source } \\
\hline $0<\beta_{P}<1$ & 0.9925 & time discount factor patient hh & Iacoviello (2015) \\
$0<\beta_{I}<1$ & 0.940 & time discount factor impatient hh & Iacoviello (2015) \\
$0<\beta_{E}<1$ & 0.940 & time discount factor entrepreneurs & Iacoviello (2015) \\
$0<\beta_{B}<1$ & 0.945 & time discount factor for banks & Iacoviello (2015) \\
$j$ & 0.075 & real estate weight in utility & Iacoviello (2015) \\
$\eta$ & 2.000 & weight of leisure in utility & Iacoviello (2015) \\
$m_{I}$ & 0.900 & loan-to-value ration - impatient hh & Iacoviello (2015) \\
$m_{E H}$ & 0.900 & loan-to-value ration - entrepreneurs & Iacoviello (2015) \\
$m_{E N}$ & 1.000 & advanced wage payment for entrepr. & Iacoviello (2015) \\
$\rho_{I}$ & 0.711 & inertia impatient's borr. constr. & Iacoviello (2015) \\
$\rho_{E}$ & 0.631 & inertia entrepreneur's borr constr. & Iacoviello (2015) \\
$\rho_{B}$ & 0.234 & inertia in bank's capital adequacy & Iacoviello (2015) \\
$\gamma$ & 0.900 & bank's liabilities to asset ratio & Iacoviello (2015) \\
$v$ & 0.050 & share of real estate in output & Iacoviello (2015) \\
$\sigma$ & 0.3273 & wage share in output & Iacoviello (2015) \\
$\gamma_{Y}$ & 0.130 & reaction of transfers to output & Leeper et al. (2010) \\
$\gamma_{B}$ & 0.500 & reaction of transfers to debt & Leeper et al. (2010) \\
$0<\frac{G^{c}}{Y}<1$ & 0.250 & government spending & calibration \\
$0<\frac{B}{Y}<1$ & 0.530 & debt to output ratio & data \\
$\tau^{W}$ & 0.220 & effective labour income tax & data \\
$\tau^{H}$ & 0.014 & average housing tax & data \\
$\tau^{C}$ & 0.023 & average consumption tax & Leeper et al. (2010) \\
$\tau r$ & 0.000 & lump-sum transfers & assumption \\
$\rho_{A_{Z}}$ & 0.950 & AR(1) coefficient of TFP & Iacoviello (2015) \\
$\rho_{g}$ & 0.800 & AR(1) coefficient of gov. spending & data \\
$\rho_{A^{J}}$ & 0.990 & AR(1) coef. of housing demand & Iacoviello (2015) \\
$\rho_{A^{M}}$ & 0.850 & AR(1) coef. of LTV ratio & Iacoviello (2015) \\
\hline
\end{tabular}

Furthermore, in our model we calibrate the government spending over output ratio so as to get a steady-state debt to output ratio of about $53 \%$, in annual terms. The data we used on total public debt are for the period 1979-2014 from FRED. ${ }^{13}$ As a result the implied government spending to output ratio in our model is about $25 \%$. Moreover, we normalize transfers to be equal to zero at the steady-state.

\footnotetext{
${ }^{12}$ Note that here we assume that all the transfers rules are identical. An interesting extension of the paper would be to estimate the various rules for each agent and then assess the impact of the policy reforms. We leave that for future research.

${ }^{13}$ The series for total public debt refers to GFDEBTN series published by FRED.
} 
The effective labour income tax is calculated using data from ECFIN and applying Martinez-Mongay (2000) approach. ${ }^{14}$ Regarding the property tax we use data from the Minnesota Taxpayers Association (2011) study.

For the calibration of the autocorrelation parameter of the government spending series we utilize annual data from the U.S. BEA for the period 1979$2014 .^{15}$ We then estimate the persistence of the AR(1) process, $\rho_{g}$, using the cyclical component of the series through an HP-filter. In addition, the constant terms of the TFP, housing demand and loan-to-value ratio processes are normalized to unity and their autocorrelation parameters are set similar to Iacoviello (2015).

\section{Solution and results}

In order to analyze the role of banks on the economy we also create another economy without banks for comparison. In that case the patient households become the financial intermediary instead of banks and provide loans to impatient households and entrepreneurs, similarly to Iacoviello (2005) and Alpanda and Zubairy (2016).

\subsection{Impulse response analysis}

\subsubsection{Testing the empirical validity of the model}

Initially, we want to check the effects of the banking sector to the economy following a temporary positive total factor productivity (TFP) and government spending shock. The case of the TFP shock is being used to establish the empirical plausibility of our model. We also show the impulse responses of the main variables under a temporary positive shock to housing demand and loan-to-value ratio to further assess our model.

\section{Figures 1-4}

Figure 1 presents the impulse responses under a temporary 1\% increase in TFP. The results for consumption and output do not differ significantly between the case with and without banks, similarly to Iacoviello (2015). However, our results indicate that without banks the TFP shock will increase the deposits and loans substantially in the short run due to the higher disposable

\footnotetext{
${ }^{14}$ In particular, we use the LITR rate for effective average labour income tax. The exact data series required for this construction are described in Martinez-Mongay (2000).

${ }^{15}$ This series refers to government consumption expenditures and gross investment from NIPA Table 1.1.5.
} 
income via transfers and the elimination of the capital adequacy constraint. This leads to higher stock of real estate for the borrowers and lower for the savers. Moreover, debt will deviate from its steady state more for the case with banks because patient households are restricted from transforming their saving to investment, due to the bank's capital adequacy constraint, leading to higher investment in bonds. Finally, patient households manage to keep a similar level of consumption compared to the case with banks even with a lower supply of labour due to the higher returns from bonds and deposits.

Figure 2 presents the impulse responses from a temporary $1 \%$ increase in government spending. In this case, similarly to the TFP case, deposits fluctuate slightly more without banks compared to the case with banks. The drop in the deposits, due to the imposed fiscal rule and the higher real estate stock of patient households, leads also to a drop in the loans and the real estate stock as a consequence. Moreover, the wage rates will decline more in the case without banks because of the lower loans the entrepreneurs receive and the assumed restriction of paying their wage bill in advance. Finally, debt deviates more in the case with banks, similarly to the TFP case discussed earlier.

In Figure 3 we present the case of a positive temporary shock to loanto-value ratio. This shock imposes a stronger borrowing constraint since additional loans require a higher collateral. As a result, the stock of housing for the borrowers increases immediately after the shock, leading to a higher level of deposits. Overall consumption decreases initially, due to the lower consumption of the patient households after their increase in deposits. Moreover, we observe that the economy under no banks exhibits more volatility mainly due to the elimination of the capital adequacy constraint. There is also an asymmetric reaction in the level of debt under the case with and without banks due to the stronger increase in output which leads to a pronounced reduction in transfers.

Finally, Figure 4 shows the impulse responses of a temporary one percent increase in housing demand. This shock leads to an increase in house prices which relax the financial frictions of the borrowers. As a result, borrowers' consumption and loans increase. Under this shock we do not observe any significant differences between the two economies with and without banks, similarly to Iacoviello (2015).

\subsection{Optimal fiscal policy}

Having established the empirical plausibility of our model with the above impulse responses we are now going to assess the optimal fiscal policy recom- 
mendation under each shock. ${ }^{16}$ In other words, we want to assess the impact to the economy when we allow the central planner (government) to optimally choose one fiscal policy instrument (tax rate) in each case under a balanced budget restriction. Therefore, we assume that the central planner cannot issue debt to fund the higher level of spending or lower level of revenue, as we assumed in the exogenous fiscal policy, similarly to Stockman (2001) and Angelopoulos et al., (2017). ${ }^{17}$

To solve the optimal fiscal policy problem the government chooses the fiscal instrument(s) to maximize aggregate welfare subject to the optimality conditions of households, entrepreneurs and banks and the government budget constraint along with the fiscal rule for transfers under commitment. Our aim is to identify the optimal fiscal policy reaction in terms of distorting taxes when the government cannot use debt or a non-distorting policy instrument to absorb the fiscal implications of various shocks to the economy (see, for example, Angelopoulos et al. (2017) for a similar application).

\subsubsection{Adjusting one fiscal policy instrument}

Taking the above into consideration, it is expected that for the case where only one fiscal instrument adjusts under each shock, the tax rate will need to increase to balance out the budget constraint of the government under a negative shock to output (i.e. negative TFP shock) or a positive shock to government spending. However, the optimal change of each tax rate and its effect to the economy is not anticipated and each instrument affects the economy differently. Therefore, this experiment will help us understand the transmission mechanisms of each fiscal instrument.

Figures 5 and 6 show the impulse responses of output and consumption (first and second row) as well as the fiscal instrument we allow to optimally adjust each time (last row) with and without banks. Specifically, Figure 5 illustrates the cases of a temporary negative TFP shock (first three columns) and a positive government spending shock (last three columns), whereas Figure 6 shows the cases of a temporary positive shock to loan-to-value ratio (first three columns) and a negative housing demand shock (last three

\footnotetext{
${ }^{16}$ Note that we are going to implement shocks that create a negative effect on output.

${ }^{17}$ If we allow debt to be chosen optimally in our setup will lead to unrealistically high level of capital tax (more than 100\%) during the first period so as to finance debt. In the subsequent periods debt turns to assets and capital tax (housing in our case) goes to zero. This result is mainly theoretical and without any empirical/realistic aspect due to the confiscatory capital tax in the first period to fully fund debt. In addition, assuming an optimal fiscal policy under a balanced budget restriction is empirically relevant since under the current economic climate many advanced countries are restricted from issuing more debt to finance higher government spending.
} 
columns).

\section{Figures 5-6}

As we can see, taxes increase under a negative shock to the economy to compensate the loss in the tax revenues and balance out the government budget constraint. In addition, taxes also increase to fund the increase in government spending.

In more detail, we observe that consumption tax reacts stronger to the shocks compared to the other taxes to balanced out the budget constraint since it is assumed to have a very low tax base. In addition, under the government spending shock, the consumption tax has a very limited effect on output and mainly reduces the level of consumption, similarly to FernandezVillaverde (2010). Housing tax affects only the intertemporal choices of the agents and as a result it is the least distorting instrument for the economy when it is used as a shock absorber. Therefore, we observe that when we allow for housing taxes to adjust output and consumption do not deviate as much from their steady state. In addition, under an increase in government spending, the use of housing tax can even lead to an increase in output. ${ }^{18}$ Finally, labour income taxes are the most distorting fiscal instrument as they affect the intratemporal decisions of the agents. This leads to a significantly stronger reduction in output and consumption when they are used as a shock absorbing mechanism.

Comparing the cases with and without banks we observe that the existence of banks can mitigate the negative spill over effects to the economy from the use of optimal fiscal policy and the associated increase in the tax rates to balance the government budget constraint. ${ }^{19}$ This is even more pronounced under the case where the labour taxes adjust. In that case the existence of banks can lead to a significantly lower reduction in output and consumption. Therefore, under the case of constrained banks, that effectively control the amount of savings transformed into investment goods, the negative effects from a higher labour income tax are mitigated, whereas under a frictionless economy, where patient households provide the loans without any constraint, these effects are amplified. ${ }^{20}$ This result provides an interesting extension of

\footnotetext{
${ }^{18}$ This is consistent with the optimal taxation literature which shows that capital taxes are the least distorting fiscal instrument and they should be used to absorb any shocks (i.e. Stockman, 2001 and Angelopoulos et al., 2016).

${ }^{19}$ Note here that the impulse responses of positive and negative shocks are symmetric. Therefore, comparing the negative TFP shock in Figure 5 under optimal fiscal policy, for example, with the positive TFP shock in Figure 1 without optimal fiscal policy is straightforward.

${ }^{20}$ Note that without banks all savings can be transformed into investment goods at no cost.
} 
Iacoviello (2015) that shows that banks matter only for the case where there are redistribution shocks that transfer resources away from banks. Our result intuitively means that due to the higher labour income tax the households would like to smooth their consumption via the use of their savings (patient households) and loans (impatient households). However, the existence of banks prevents the frictionless transformation of savings to investment goods, controlling the propagation of the shocks to the economy.

\subsubsection{Using a combination of fiscal instruments}

In this section we allow for the government to optimally choose two fiscal instruments at a time. Thus, the bundles of possible used fiscal combinations are: $\tau^{W}-\tau^{H} ; \tau^{W}-\tau^{C}$; and $\tau^{H}-\tau^{C} .^{21}$

Allowing for two tax rates to optimally adjust creates an interesting puzzle to the central planner. In the previous section, the central planner couldn't set the value of the tax rate at any level optimally, since it was constrained to be used so as to balance out the budget. Now, given the financial frictions of our model that introduce an additional intertemporal distortion, the central planner needs to optimally choose a combination of distortionary taxes to restore efficiency in intertemporal margins and also balance the budget constraint. Thus, the central planner should optimally choose the tax rates so as to minimize the distortions to the economy from increased taxes and also alleviate the inefficiencies caused by the financial frictions.

Figures 7 and 8 replicate the experiments of the previous section, as shown in Figures 5-6, with the addition of a second tax rate in the optimal fiscal policy menu. Therefore, Figure 7 shows again the impulse responses under a temporary negative TFP shock (first three columns) and a positive government spending shock (last three columns), whereas Figure 8 shows responses to a temporary positive shock to loan-to-value ratio (first three columns) and a negative housing demand shock (last three columns). The last two rows in each figure show the two tax rates that optimally adjust in each scenario.

\section{Figures 7-8}

Comparing these results with the case where the government could only choose one fiscal instrument, we observe that there is a lower reduction in

\footnotetext{
${ }^{21}$ It is not possible to allow for all three fiscal instruments to be optimally chosen at once because there is no unique steady state to this problem. This is straightforward to proof. Using equations A1-A4 for Patient households, for example, presented in the appendix we can show that equations A2 and A4 at the steady state give the arbitrage condition for the interest rate of deposits and bonds. Then we have two equations A1 and A3 to pin down three tax rates which leads to indeterminacy.
} 
output and in some instances it can even increase. Therefore, the government is more efficient under a richer basket of policy instruments. This is consistent with the related optimal fiscal policy literature that shows a Pareto improvement outcome under a full set of fiscal instruments, e.g. Correia (1999).

In addition, we find that the government will avoid using labour tax as a shock absorbing mechanism due to its highly distortive nature. As a result, the alternative policy instrument (either housing or consumption tax) is mainly used to balance the budget constraint of the government. This is also consistent with the labour tax smoothing result of the related optimal taxation literature (i.e. Chari et al., 1994 and Angelopoulos et al., 2015).

Finally, we observe that under the case without banks the economy is more volatile and the optimal reaction of the various fiscal instruments is stronger under each shock, as in the previous case where the government could only use one fiscal instrument optimally.

\subsection{Aggregate effects on output}

Tables 2 and 3 summarize the effects on output under exogenous (Table 2) and under optimal fiscal policy (Table 3) as a percent deviation from the steady state following a one percent temporary shock, as illustrated in each row of the table. The shocks presented in these tables are the same shocks we have implemented at the impulse responses under optimal fiscal policy above.

Starting with the case of a negative shock to TFP we observe that the use of optimal fiscal policy and the associated distortionary taxes, generates a stronger negative effect on output. This negative effect is even higher without banks in the majority of the experiments. There is only a short run positive effect on output under optimal fiscal policy with labour and housing taxes. This is mainly driven from the significantly lower labour tax rate which affects positively the intratemporal margin leading to positive short run economic effects. The increase in the housing tax affects negatively only the intertemporal margin. Therefore, in the first period after the shock low labour taxes drive the positive effect on output which quickly turns negative in the subsequent periods due to the higher housing tax. In the long run every case derives negative effects on output of about 0.1-0.2 percent apart from the case under labour taxes and no banks, where the negative effect on output is doubled.

Regarding the government spending shock we can see that under an exogenous fiscal policy regime it is better for debt to adjust so as to balance the budget constraint of the government (exogenous fiscal policy regime) and 
not any individual distortionary fiscal instrument. However, we can see that when the government can optimally choose any two fiscal instruments it is better to adjust labour and housing taxes, which will increase output significantly in the short run, similarly to the TFP case. In the long run there are no significant benefits for output from a temporary increase in government spending, irrespective of the financing method. ${ }^{22}$

Following the temporary increase in the loan-to-value ratio we observe that there is a negative effect on output in the short run. However, in the medium and long run there are positive effects on output. This means that the initial tightening on loans creates additional incentives for the constraint agents to increase their savings and their stock of housing leading to higher future output via its input in the production process. Moreover, we observe that when housing and consumption taxes are used optimally there will be significant positive effects on output even in the short run. As we have shown in the impulse responses earlier, under this scenario the housing tax reduces significantly enhancing the accumulation of housing. We also observe that, in general, under no banks the effects on output are more pronounced.

Finally, under the case of a negative temporary decrease in housing demand we observe a short run increase in output in the majority of the experiments we perform. This shock leads to an increase in house prices which relax the financial frictions of the borrowers creating an increase in loans and stock of housing. Those effects increase consumption and output in the short run. However, as house prices decrease the agents increase their savings via a reduction in consumption and stock of housing (mainly for entrepreneurs), creating a negative effect on output. In the long run we observe that output exhibits a marginal decrease compared to the steady state. This result is robust under each scenario of optimal fiscal policy with the exception of the case with labour and housing taxes. In this case the government is able to generate large positive output effects in the short run via the initially low labour taxes which are sufficient to create a marginally positive long run

\footnotetext{
${ }^{22}$ As we discussed earlier, this is mainly due to the assumption that government spending are not productive in this model.
} 
effect.

Table 2: Effects on output as a percent deviation from the steady state under exogenous fiscal policy

\begin{tabular}{ccccc}
\hline \hline & $T=t+1$ & $T=t+10$ & $T=t+100$ & $T \rightarrow \infty$ \\
& \multicolumn{4}{c}{ Panel A: With Banks } \\
\hline$T F P$ & -0.8869 & -0.7202 & -0.2393 & -0.1521 \\
$G$ & 0.1428 & 0.0562 & 0.0092 & 0.0058 \\
$A^{M}$ & -0.0075 & 0.0097 & 0.0018 & 0.0011 \\
$A^{J}$ & -0.0731 & -0.0337 & 0.0052 & 0.0046 \\
\hline \multicolumn{5}{c}{ Panel B: Without Banks } \\
\hline$T F P$ & -0.8811 & -0.7272 & -0.2331 & -0.1481 \\
$G$ & 0.1521 & 0.0574 & 0.0100 & 0.0064 \\
$A^{M}$ & -0.0201 & 0.0186 & 0.0020 & 0.0013 \\
$A^{J}$ & -0.0596 & -0.0369 & 0.0063 & 0.0054 \\
\hline
\end{tabular}

\subsection{Welfare effects}

In this section we report the welfare effects from the various cases presented above using the consumption equivalence approach. Assuming that the welfare of each agent under optimal fiscal policy is given by $W_{J}^{f p}$ and under exogenous fiscal policy by $W_{J}^{0}$, then the consumption equivalent gain/loss of each agent under each shock is calculated as:

$$
\begin{gathered}
W_{J}^{0}\left(\lambda_{j}, C_{j}^{0}, H_{j}^{0}, N_{j}^{0}\right)=W_{J}^{f p}\left(C_{j}^{f p}, H_{j}^{f p}, N_{j}^{f p}\right) \\
\sum_{t=0}^{\infty} \beta_{j}^{t} U\left(\left(1+\lambda_{j}\right) C_{j}^{0}, H_{j}^{0}, N_{j}^{0}\right)=\sum_{t=0}^{\infty} \beta_{j}^{t} U\left(C_{j}^{f p}, H_{j}^{f p}, N_{j}^{f p}\right)
\end{gathered}
$$

where $\lambda_{j}$ is the consumption equivalent gain/loss of the use of optimal fiscal policy for each source of uncertainty.

Using the logarithmic utility function applied in our analysis we get the following expression for the consumption equivalent gain/loss:

$$
\lambda_{j}=\exp \left(\left(W_{J}^{f p}-W_{J}^{0}\right) \frac{1}{\sum_{t=0}^{\infty} \beta_{j}^{t}}\right)-1
$$




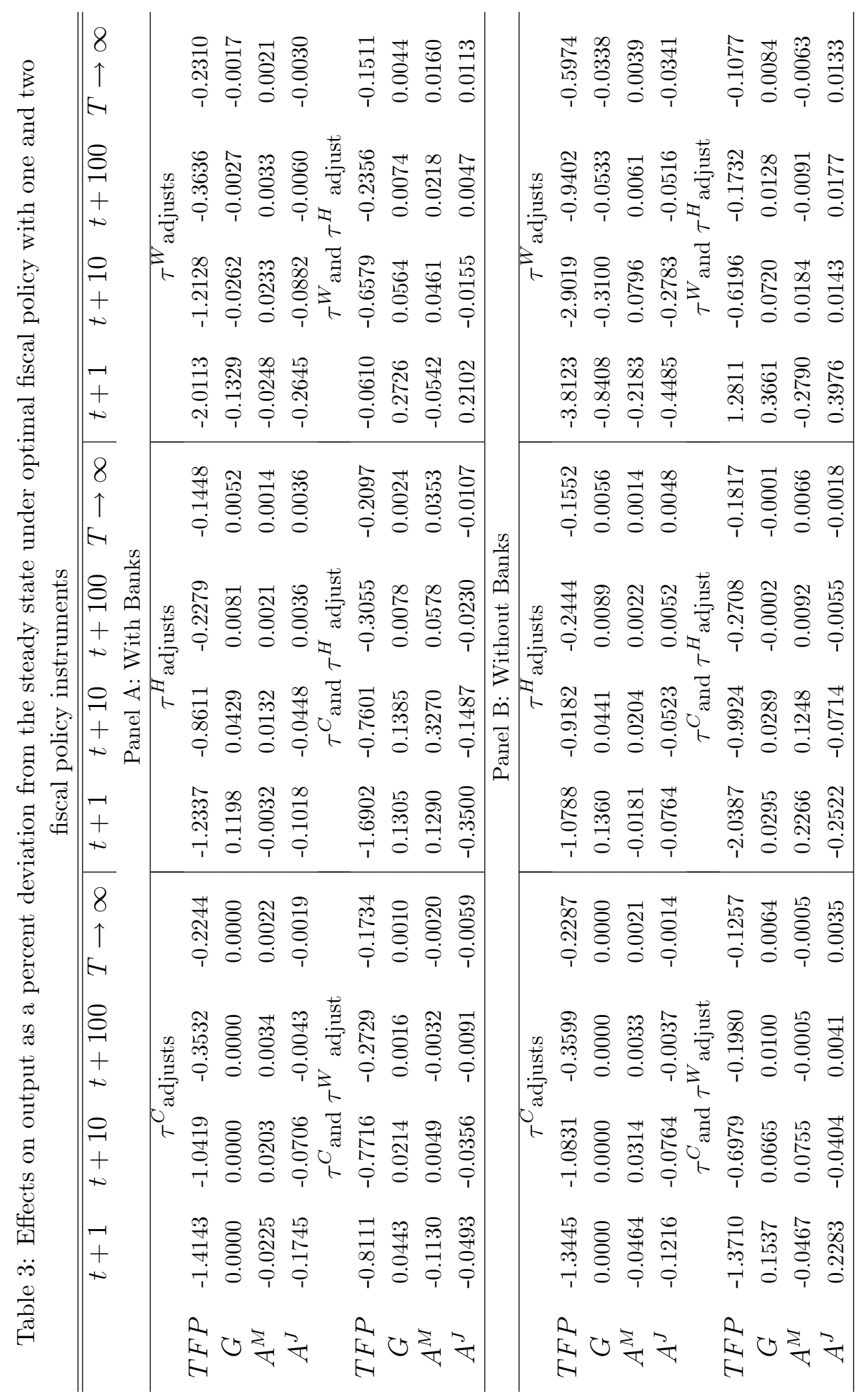


Tables 4 and 5 present the values of the consumption equivalent in percentage terms for each agent (in columns) and for each temporary shock (in rows). We should note here that the steady state of our economy is different for the case with and without banks, similar to Iacoviello (2015). In particular, the capital requirement constraint of the banks is not present under the no-banks case and as a result there are no frictions in the transformation of savings to investment. This leads to higher levels of consumption, stock of real-estate and loans in the economy without banks. This needs to be taken into account when we perform the welfare analysis below.

Positive values indicate that the agent is better off under the optimal fiscal policy and vice versa. Moreover, the values reported in Tables 4 and 5 are for $t \rightarrow \infty .^{23}$

Under the exogenous fiscal policy (Table 4) we observe similar welfare effects for the two cases, with and without banks. The only difference appears to be in the case of a positive shock to loan-to-vale ratio, $A^{M}$, where the impatient household is better off under no banks since, in this case, there is an unconstraint provision of loans from the patient households. Moreover, under exogenous fiscal policy the existence of banks mitigates the negative welfare effects for borrowers under the temporary negative housing demand shock.

Moving to the case of optimal fiscal policy (Table 5) we need to mention that the central planner maximizes the aggregate welfare of the economy. Therefore, it is natural to observe asymmetries and differences in the welfare of each agent under each scenario. In these experiments it might be optimal for one agent to be better off while the others are worse off compared to the exogenous fiscal policy case. In more detail, we observe that under a temporary negative TFP shock the welfare of impatient households is the one that decreases the most. This is even more pronounced under the case of a labour tax (especially without banks), since they are financially constraint and not able to smooth out their consumption.

Under a temporary positive government spending shock, $G$, we observe that the welfare of patient households is generally stable. However, the welfare of the borrowers improves when the government has access to two fiscal policy instruments. This result remains relatively valid even when banks are not present. Therefore, financing increased government spending via a combination of tax rates and not debt leads to a Pareto improvement, especially from the borrowers perspective.

The case of a temporary increase in the loan-to-value ratio shock, $A^{M}$,

\footnotetext{
${ }^{23}$ We also have the results for intermediate periods but we do not present them here to save space. These results are available on request.
} 
creates significant welfare gains for the borrowers when housing tax is used together with consumption tax. This result confirms our earlier findings showing that the lower housing tax enhances the accumulation of real estate for borrowers. Moreover, when housing tax is used together with labour income tax, we observe that impatient households are mainly better off, from the borrowers point of view, due to the direct effect of the lower labour income taxes on their consumption and welfare as a consequence.

Finally, the case of a temporary negative housing demand shock, $A^{J}$, creates marginal welfare gains for the impatient households when labour income tax is optimally chosen together with either consumption or housing tax. Entrepreneurs mainly benefit from the coexistence of housing tax with another fiscal instrument. However, these benefits disappear when banks are not present with the exception of the labour and housing tax case where impatient households benefit more due to the pronounced reduction in the labour income tax.

Table 4: Welfare effects (\% of consumption equivalent) under exogenous fiscal policy

\begin{tabular}{|c|c|c|c|c|}
\hline & Patient hh & $\begin{array}{l}\text { Impatient hh } \\
\text { Panel A: With }\end{array}$ & $\begin{array}{l}\text { Entrepr. } \\
\text { Banks }\end{array}$ & Bank \\
\hline$T F P$ & -0.1606 & -0.9514 & -1.1230 & -0.8471 \\
\hline$G$ & -0.0040 & -0.1380 & -0.1137 & -0.1994 \\
\hline$A^{M}$ & 0.0021 & -0.0049 & 0.0049 & 0.6033 \\
\hline$A^{J}$ & 0.0099 & -0.0998 & -0.1851 & -0.6510 \\
\hline & \multicolumn{4}{|c|}{ Panel B: Without Banks } \\
\hline$T F P$ & -0.1874 & -0.9104 & -0.9475 & - \\
\hline$G$ & -0.0049 & -0.1417 & -0.1059 & - \\
\hline$A^{M}$ & 0.0011 & 0.0253 & -0.0025 & - \\
\hline$A^{J}$ & 0.0096 & -0.1324 & -0.2379 & - \\
\hline
\end{tabular}

\section{$5 \quad$ Exogenous policy experiments}

In this section we would like to examine the impact on the economy under exogenous fiscal policy reforms. These policy reforms are assumed to be exogenous and permanent changes (increases) in each tax rate. We believe that this is empirically relevant since, after the recent financial and sovereign debt crises, most of the developed countries face high level of debt and there is the need to reduce it via higher taxation. In addition, many countries have announced the increase in their level of public spending in an effort to increase the observed low levels of economic growth. 


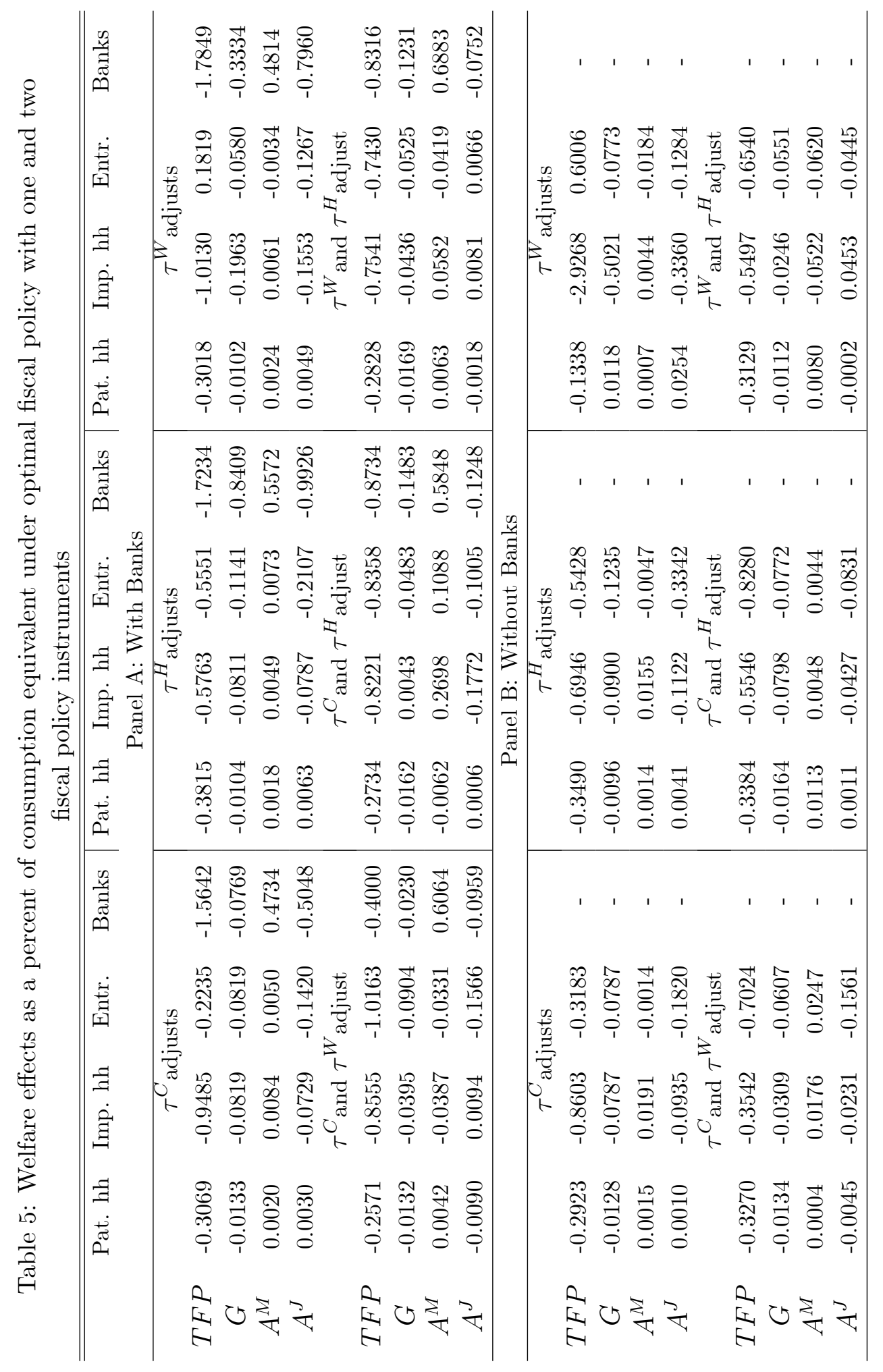


This creates an interesting puzzle for the policy-makers regarding the use of the most appropriate source of financing the increased public spending and high level of debt. Here we assume that the government is able to change (increase) permanently one fiscal instrument at a time as a source of funding. This will generate negative spillover effects to the economy and welfare of each agent which need to be taken into account. At the previous sections we have shown what should be the optimal fiscal policy under temporary shocks. Now though we are interested in assessing the effects on the economy following permanent changes of fiscal instruments under no uncertainty. Moreover, given our model setup, we also aim at assessing the role of banks to these fiscal policy reforms.

Taking the above into consideration, Table 6 presents the effects on output from a permanent $1 \%$ increase in government spending $(G)$, housing tax $\left(\tau^{H}\right)$, labour tax $\left(\tau^{W}\right)$ and consumption tax $\left(\tau^{C}\right) \cdot{ }^{24}$ The variable in the brackets in the first column of Table 6 indicates the residual instrument that adjusts following the permanent fiscal policy reform to balance the government budget constraint. For example, under the case of $G\left(\tau^{W}\right)$ we have a $1 \%$ increase in government spending financed by higher labour income taxes. In addition, we perform this analysis for the case with banks (Panel A) and for the case without banks (Panel B).

In terms of the government spending shock (first row in each panel) we observe that the results are similar in both cases, with and without banks, when it is financed via debt. This is probably due to the fact that we have assumed that government spending is not-productive in our setup ${ }^{25}$.

Under the case of higher government spending we also assess the effects on output under different financing methods (housing, labour and consumption taxes). These experiments are directly comparable to the optimal fiscal policy analysis performed in the previous section where we allowed one fiscal instrument to adjust optimally to a temporary increase in government spending keeping debt level fixed. The only difference is that now we have a

\footnotetext{
${ }^{24}$ Another approach would be to use a policy reform that would raise a certain amount of tax revenue as a share of output, i.e. $2 \%$ of output. Applying a change that will raise a certain amount of income can be highly unbalanced for certain taxes. For example, the returns from the consumption tax on entrepreneurs is $0.15 \%$ of output. Therefore, this tax would need to increase about 12 times to raise the required income, whereas their housing tax returns are about $1.75 \%$ of output and they would need to double. As a result, this approach would not be helpful for our welfare analysis and comparison later on. In addition, the main focus of the paper is on the qualititative aspect of the effects and not on their magnitude.

${ }^{25}$ Asimakopoulos et al. (2017) provide an analysis on how productive government spending affect the economy and consumption in particular.
} 
permanent increase in government spending.

Table 6: Effects on output as a percentage deviation from the steady-state

\begin{tabular}{ccccc}
\hline \hline & $T=t+1$ & $T=t+10$ & $\begin{array}{c}T=t+100 \\
\text { Panel A: With Banks }\end{array}$ & $T \rightarrow \infty$ \\
\hline$G(B)$ & 0.1233 & 0.1299 & 0.1363 & 0.1367 \\
$G\left(\tau^{H}\right)$ & -0.2836 & -0.1272 & 0.1155 & 0.1331 \\
$G\left(\tau^{W}\right)$ & -0.0804 & -0.0472 & -0.0013 & 0.0018 \\
$G\left(\tau^{C}\right)$ & 0.0000 & 0.0000 & 0.0000 & 0.0000 \\
$\tau^{H}(B)$ & -0.0569 & -0.0369 & -0.0030 & -0.0004 \\
$\tau^{W}(B)$ & -0.1202 & -0.1122 & -0.1017 & -0.1009 \\
$\tau^{C}(B)$ & -0.0083 & -0.0088 & -0.0092 & -0.0092 \\
\hline & & Panel B: Without Banks \\
\hline$G(B)$ & 0.1252 & 0.1302 & 0.1398 \\
$G\left(\tau^{H}\right)$ & -0.1919 & -0.1884 & 0.1147 & 0.1403 \\
$G\left(\tau^{W}\right)$ & -0.7120 & -0.7311 & -0.6738 & 0.1349 \\
$G\left(\tau^{C}\right)$ & 0.0000 & 0.0000 & 0.0000 & 0.0695 \\
$\tau^{H}(B)$ & -0.0428 & -0.0441 & -0.0035 & -0.0005 \\
$\tau^{W}(B)$ & -0.2079 & -0.2099 & -0.2090 & -0.2089 \\
$\tau^{C}(B)$ & $-0.4 \mathrm{e}^{-4}$ & -0.0251 & -0.0193 & -0.0184 \\
\hline
\end{tabular}

We observe that when government spending is financed via a housing tax there is a reduction in output in the short-run which only becomes positive in the long-run. This is in contrast to the temporary shock presented in the previous section were we observed positive economic effects from the impact of the shock due to the anticipated reduction in housing tax in the future. In addition, when government spending is financed via higher labour income tax we observe similar results to the temporary shock under optimal fiscal policy for both cases, with and without banks. Specifically, we find again a more pronounced negative effect on output when labour income tax is increased to finance spending when banks are not present. Finally, consumption tax has again no significant effect on output, which is consistent with our results under optimal fiscal policy and Fernandez-Villaverde (2010).

In the case of a higher housing tax financed via debt we observe similar patterns in both cases. However, we should note here the stronger initial reaction of the economy to a permanent $1 \%$ increase in the real estate tax when banks are present. Even in the case without banks the borrowing constraints are still present but the patient households are not constraint in providing loans, in contrast to the banks that are subject to the capital adequacy constraint. Therefore, the initial impact of the housing tax is stronger with banks, but in the long run banks can mitigate the impact with 
minor spillover effects to the economy. That happens mainly through the restriction of transforming savings to investment.

In particular, the increase of housing tax has a stronger negative impact on patient households. Patient households reduce their housing stock due to the higher tax and they also reduce their labour supply due to the higher inflow of transfers following the decline in output and debt. The effects on impatient households are similar. Entrepreneurs though react differently to the higher real estate tax because housing is not welfare enhancing for them. They only have indirect gains through the use of real-estate as an input in the production process. Therefore, the households care more about increasing their housing stock compared to the entrepreneurs due to the direct utility gains. Finally, the results are qualitatively similar with and without banks.

The results form the labour income tax policy reform are very interesting. Under the case with banks the effect of a permanent increase in the labour income tax is negative to the economy with an initial decrease of about $0.12 \%$ in output. In the long run though this initial negative effect slowly decreases and in the long run it stabilizes at about $-0.1 \%$. When we move on to the case without banks we observe that the negative effect on the economy is doubled. In addition, this higher initial negative impact on the economy doesn't decline in the long-run, as in the case with banks, and it stays at the level of about $-0.21 \%$, which is two times higher compared to the negative effect in the economy for the case with banks.

Therefore, under the case of constrained banks, that effectively control the amount of savings transformed into investment goods, the negative effects from a higher labour income tax are mitigated, whereas under a frictionless economy, where patient households provide the loans without any constraint, these effects are amplified. This result verifies our findings in the previous section where we allowed for the government to optimally choose the labor tax rate under uncertainty. ${ }^{26}$

Finally, under the case of a permanent increase in the consumption tax we observe that the initial negative impact on the economy is stronger with banks and milder without banks. However, in the long run we find that the negative spillover effect to output is two times higher compared to the case with banks.

Overall, the various fiscal policy reforms presented above show that the least favorable tax rate to be used to finance debt and/or higher government

\footnotetext{
${ }^{26}$ Having a labour tax on patient households without banks is similar to having a reduction in the net worth of banks. As Iacoviello (2015) has shown, a reduction in the net worth of banks leads to a reduction in the supply of loans affecting output. Therefore, the negative spillover effects to the economy from an increase in the labour income tax of patient households are amplified under the no-banks case.
} 
spending is the labour income tax. This is again in line with our earliest results and with the labour tax smoothing literature which shows that capital taxes should be used as a shock absorbing mechanism and not labour taxes, i.e. Chari et al. (1994). However, these experiments show an interesting asymmetry in the quantitative effect of the change in labour income tax with and without banks.

\subsection{Welfare effects of fiscal policy reforms}

In this section we report the welfare effects from the various policy reforms presented above using the consumption equivalence approach as in the case with optimal fiscal policy. Here we assume that the welfare of each agent after the policy reform is given by $W_{J}^{p r}$ and before the policy reform by $W_{J}^{0}$, then the consumption equivalent gain/loss of each agent from that reform is given by: $\lambda_{j}=\exp \left(\left(W_{J}^{p r}-W_{J}^{0}\right) \frac{1}{\sum_{t=0}^{\infty} \beta_{j}^{t}}\right)-1$

Similarly to Tables 4 and 5 , the values reported in Table 7 are for $t \rightarrow \infty$. In addition, positive values indicate that the agent is better off under the policy reform and vice versa. In addition, as in Table 6 , the variable in the brackets in the first column indicates the residual instrument that adjusts following the permanent fiscal policy reform to balance the government budget 
constraint.

Table 7: Welfare effects (\% of consumption equivalent)

\begin{tabular}{ccccc}
\hline \hline & Patient hh & Impatient hh & Entrepr. & Bank \\
& \multicolumn{4}{c}{ Panel A: With Banks } \\
\hline$G(B)$ & -0.1175 & -0.3422 & -0.9852 & -0.0526 \\
$G\left(\tau^{H}\right)$ & -0.2871 & -0.5981 & -0.9334 & -1.7359 \\
$G\left(\tau^{W}\right)$ & -0.3489 & -0.4365 & -0.0667 & -0.3457 \\
$G\left(\tau^{C}\right)$ & -0.3316 & -0.3172 & -0.3172 & -0.3186 \\
$\tau^{H}(B)$ & -0.0133 & -0.0587 & -0.1063 & -0.9899 \\
$\tau^{W}(B)$ & -0.1916 & -0.0416 & 0.6573 & -0.2082 \\
$\tau^{C}(B)$ & -0.0142 & 0.0048 & 0.0424 & -0.0177 \\
\hline \multicolumn{5}{c}{ Panel B: Without Banks } \\
\hline$G(B)$ & -0.0731 & -0.3984 & -1.1023 & - \\
$G\left(\tau^{H}\right)$ & -0.2092 & -0.7844 & -0.9198 & - \\
$G\left(\tau^{W}\right)$ & -0.0493 & -1.4781 & 0.7207 & - \\
$G\left(\tau^{C}\right)$ & -0.3196 & -0.3056 & -0.3056 & - \\
$\tau^{H}(B)$ & -0.0144 & -0.1079 & -0.1942 & - \\
$\tau^{W}(B)$ & 0.0645 & -0.1984 & 0.4505 & - \\
$\tau^{C}(B)$ & -0.0375 & -0.0876 & 0.1817 & - \\
\hline
\end{tabular}

The results in Panel A and Panel B of Table 7 show that the welfare of every agent is decreasing under the case of higher government spending, irrespective the method of financing, with a more significant effect on the borrowers.

When the higher government spending is financed via debt (first row) it also affects negatively the transfers via the fiscal rules, causing a reduction in the disposable income. Agents that are borrowers, impatient households and entrepreneurs, rely more on their disposable income compared to patient households. Hence we observe larger negative welfare effects for them.

We also assess the cases where government spending is financed via either housing tax or labour income tax or consumption tax. These results are again comparable with that of Table 5, where we had one fiscal instrument to adjust optimally at a time, with the only difference that now we have a permanent increase in government spending. As a result the welfare effects we obtain in Table 7 are even more pronounced compared to that of Table 5 from the use of distortionary taxes as a method to finance higher government spending.

For the case of a higher real estate tax we observe similar reaction in the welfare of all agents in Panel A and B. It is noticeable though that the welfare decrease is larger for the borrowers when there are no banks.

The welfare of both households is reduced under a higher labour income tax when banks are present, with higher decrease in the welfare of patient 
households. However, when banks are not present we observe a significant increase in the welfare of the patient households, whereas the entrepreneurs are still better off because they are not subject to a labour tax and they receive higher transfers due to the income redistribution. However, the difference between the two households is amplified under the no-banks case, which means that patient households gain all the benefits from the income redistribution and their ability to smooth out their consumption.

Regarding the consumption tax, under the case with banks patient households are negatively affected from the income redistribution via transfers, whereas impatient households and entrepreneurs are positively affected. Banks are negatively affected as expected since we have assumed that they do not receive any lump-sum transfers. However, in the case without banks, only the entrepreneurs gain from the income redistribution via the higher consumption tax.

\subsection{Robustness checks}

In this subsection we assess the spillover effects to the economy from the fiscal policy reforms under several assumptions around the imposed financial constraints. The ultimate aim of this analysis is to assess how the change in the financial frictions can affect the transmission of the shocks to the economy. Thus, Table 8 presents the results in terms of percentage change in output from the benchmark steady state. These results can then be directly compared to the last column of Table 6 and for the case with banks, to assess whether the imposed structural changes assumed in this section can boost the economy. ${ }^{27}$

Under the first experiment we assume that bank's adequacy of capital is lower, $\rho_{B}^{\text {new }}=0.5 \rho_{B}$ (first column in Table 8). In this case we do not observe significant changes compared to our benchmark calibration.

Then we assess the case where bank's liabilities to asset ratio is reduced, $\gamma^{\text {new }}=0.75 \gamma$, which means that banks face a stricter screening process for giving out their loans (second column in Table 8). In this case the significant change appears to be on the spillover effect of housing tax to output which becomes positive. This result is driven from the higher positive effects of a higher housing tax on patient households and the decline in the negative effect from the housing tax on entrepreneurs. However, we should note that still the overall effect on the economy is very small.

Another experiment we perform is through the borrowing constraints of

\footnotetext{
${ }^{27}$ Note that in these experiments we only show the results where a policy reform is met via a change in debt to satisfy the government budget constraint.
} 
the impatient households and entrepreneurs. In particular, we assume that they are less restricted in terms of the loans they can obtain given their collateral, $m_{I}^{\text {new }}=0.75 m_{I}$ (third column in Table 8) and $m_{E H}^{n e w}=0.75 m_{E H}$ (fourth column in Table 8). In both cases, we observe only minor changes compared to the benchmark calibration coming from the higher positive spillover effects to the economy from the increased government spending and housing tax.

Finally, we assess the impact of a direct transfer to banks from the government of a size similar to the quantitative easing that took place in the US. For that reason we assume that banks receive a transfer of about $5 \%$ of the overall output in the economy (last column in Table 8). Interestingly in this case we do not observe any significant improvement to the economy apart from the minor improvement in the negative effects from the higher labour income tax. However, we should note that our results in this case are biased because we only provide transfers to banks without any other changes in the assumed financial frictions.

Overall, we conclude from these experiments that our results from the benchmark calibration are robust to changes in various parameters of the imposed financial constraints. ${ }^{28}$

Table 8: Effects on output as a \% deviation from the steady-state

\begin{tabular}{cccccc}
\hline \hline & $0.5 \rho_{B}$ & $0.75 \gamma$ & $0.75 m_{I}$ & $0.75 m_{E H}$ & $t r_{B}=y \times 5 \%$ \\
& Panel A: With Banks and aggregate policy reforms \\
\hline$G(B)$ & 0.1367 & 0.1359 & 0.1378 & 0.1364 & 0.1371 \\
$\tau^{H}(B)$ & -0.0003 & 0.0021 & 0.0028 & -0.0004 & -0.0005 \\
$\tau^{W}(B)$ & -0.1009 & -0.0997 & -0.0994 & -0.1001 & -0.0975 \\
$\tau^{C}(B)$ & -0.0092 & -0.0092 & -0.0093 & -0.0092 & -0.0096 \\
\hline
\end{tabular}

\section{Conclusions}

In this paper we introduced a fiscal sector in a real business cycle model with banks, patient and impatient households, entrepreneurs and financial frictions. We found that the existence of banks can mitigate the negative spillover effects to the economy from higher taxes under both optimal fiscal policy and various fiscal policy reforms.

Optimal fiscal policy experiments under uncertainty confirmed that labour taxes were the most distortionary fiscal policy instrument. We also found that housing tax, as a source of financing temporary increased government spending, could lead to higher output in the short run. Furthermore, the

\footnotetext{
${ }^{28}$ We have also performed similar robustness checks for the optimal fiscal policy experiments and there are no changes to our key results.
} 
combination of labour and housing taxes were, on average, the most preferred tax bundle.

In addition, the fiscal policy reforms experiments verified the optimal fiscal policy outcome of housing taxes. In addition, permanently higher housing taxes and government spending affected mostly borrowers' welfare, whereas a higher consumption tax was beneficial for impatient households when banks were present. Entrepreneurs were mainly better off following an increase in the consumption tax due to the income redistribution via transfers. We also found that a decrease in the net worth of loan suppliers amplified the negative spillover effects to the economy. Finally, our main results were robust in changes to the calibration of the financial constraints.

\section{References}

[1] Alpanda S. and S. Zubairy (2016). 'Housing and tax policy', Journal of Money, Credit and Banking, 48, 485-512.

[2] Angelopoulos, K., Asimakopoulos, S., and J. Malley (2015). 'Tax smoothing in a business cycle model with capital-skill complementarity', Journal of Economic Dynamics and Control, 51, 420-444.

[3] Angelopoulos, K., Asimakopoulos, S., and J. Malley (2016). 'Optimal progressive taxation in a model with endogenous skill supply', in Philippopoulos, A. (ed.) Public Sector Economics and the Need for Reforms. MIT Press.

[4] Angelopoulos, K., Asimakopoulos, S., and J. Malley (2017). 'The optimal distribution of the tax burden over the business cycle', Macroeconomic Dynamics, forthcoming.

[5] Asimakopoulos, S., M. Lorusso and L. Pieroni (2017). 'Can public spending boost private consumption?', Bath University Working Paper Series.

[6] Brunnermeier, M.K. and Y. Sannikov (2014). 'A macroeconomic model with a financial sector', The American Economic Review, 104 (2), 379 421.

[7] Browning, M., Hansen, L. and J. Heckman (1999). 'Micro data and general equilibrium models', in J. Taylor and M. Woodford (eds.), Handbook of Macroeconomics, 1, 543-633, Amsterdam: Elsevier. 
[8] Campbell, J. and G. Mankiw (1989). 'Consumption, income, and interest rates: Reinterpreting the time-series evidence', in O.J. Blanchard and S. Fischer (eds.), NBER Macroeconomics Annual, 185-216, MIT Press.

[9] Campbell, J. and J. Cochrane (1999). 'By force of habit: A consumptionbased explanation of aggregate stock market behavior', Journal of Political Economy, 107, 205-251.

[10] Cantore, C. and P. Levine (2012). 'Getting normalization right: Dealing with 'dimensional constants' in macroeconomics', Journal of Economic Dynamics and Control, 36, 1931-1949.

[11] Chambers, M., C. Garriga, and D.E. Schlagenhauf. (2009) 'Housing policy and the progressivity of income taxation', Journal of Monetary economics, 56, 1116-1134.

[12] Chari, V., Lawrence, C. and P. Kehoe (1994). 'Optimal fiscal policy in a business cycle model', The Journal of Political Economy, 102, 617-652.

[13] Cogan, J., Cwik, T., Taylor, J. and V. Wieland (2010). 'New Keynesian versus old Keynesian government spending multipliers', Journal of Economic Dynamics and Control, 34, 281-295.

[14] Correia, I. (1999). 'On the efficiency and equity trade-off', Journal of Monetary Economics, 44 (3), 581-603.

[15] Cui, W. (2016). 'Monetary-fiscal interactions with endogenous liquidity fictions', European Economic Review, 87, 1-25.

[16] Fernandez-Villaverde, J. (2010). 'Fiscal policy in a model with financial frictions', American Economic Review, 100 (2), 35-40.

[17] Galí, J., Lopez-Salido, D. and J. Valles (2007). 'Understanding the effects of government spending on consumption', Journal of the European Economic Association, 5 (1), 227-270.

[18] Gertler, M. and P. Karadi (2011). 'A model of unconventional monetary policy', Journal of Monetary Economics, 58 (1), 17-34.

[19] Gertler, M. and N. Kiyotaki. (2010). 'Financial intermediation and credit policy in business cycle analysis'. In: Friedman, B.M., Woodford, M. (Eds.), Handbook of Monetary Economics, vol. 3. Elsevier, pp. 547-599. Chapter 11. 
[20] Gervais, M. (2002). 'Housing taxation and capital accumulation', Journal of Monetary Economics, 49 (7), 1461-1489.

[21] Gomes, P. and H. Seoane (2017). 'Made in Europe: Monetary-Fiscal policy mix with financial frictions', mimeo.

[22] Iacoviello, M. (2005). 'House Prices, Borrowing Constraints, and Monetary Policy in Business Cycles', American Economic Review, 95, 739764.

[23] Iacoviello, M. (2015). "Financial Business Cycles," Review of Economic Dynamics, 18 (1), 140-163.

[24] Kiyotaki, N., and J. Moore (1997). 'Credit Cycles', Journal of Political Economy, 105, 211-48.

[25] Kollmann, R., Enders, Z. and G.J. Muller (2011). 'Global banking and international business cycles', European Economic Review, 55 (3), 407426.

[26] Meh, C.A. and K. Moran (2010). 'The role of bank capital in the propagation of shocks', Journal of Economic Dynamics and Control, 34 (3), $555-576$.

[27] Minnesota Taxpayers Association (2011). '50-State property tax comparison study', Saint Paul, Minnesota.

[28] Stockman, D. (2001). 'Balanced-budget rules: Welfare loss and optimal policies', Review of Economic Dynamics, 4, 438-459. 


\section{Appendix A: FOCs for patient, impatient house- holds, entrepreneurs and banks}

\section{Patient households}

The first-order conditions of patient households with respect to their choice variables are:

FOC for labour:

$$
\frac{U_{C_{P}}(t)}{\left(1+\tau_{t}^{C}\right)}\left(1-\tau_{t}^{W}\right) W_{P, t}+U_{N_{P}}(t)=0
$$

shows that patient households want to equate the after-tax returns from labour to the marginal rate of substitution between consumption and labour.

FOC for deposits:

$$
\beta_{P} E_{t}\left\{\frac{U_{C_{P}}(t+1)}{\left(1+\tau_{t+1}^{C}\right)} R_{P, t}\right\}-\frac{U_{C_{P}}(t)}{\left(1+\tau_{t}^{C}\right)}=0
$$

shows that patient households want to equate the interest income from deposits to the marginal cost of forgone consumption from higher deposits.

FOC for housing demand:

$$
\beta_{P} E_{t}\left\{\frac{U_{C_{P}}(t+1)}{\left(1+\tau_{t+1}^{C}\right)}\left(1-\tau_{t}^{H}\right) q_{t+1}\right\}+U_{H_{P}}(t)-q_{t} \frac{U_{C_{P}}(t)}{\left(1+\tau_{t}^{C}\right)}=0
$$

shows that patient households want to equate the expected after-tax return from housing to the marginal utility gain from the additional housing and the marginal cost of obtaining a higher stock of housing.

FOC for bonds:

$$
\beta_{P} E_{t}\left\{\frac{U_{C_{P}}(t+1)}{\left(1+\tau_{t+1}^{C}\right)} R_{B, t}\right\}-\frac{U_{C_{P}}(t)}{\left(1+\tau_{t}^{C}\right)}=0
$$

where $U_{C_{P}}(t)=\frac{1}{C_{P, t}}, U_{N_{P}}(t)=-\frac{\eta}{1-N_{P, t}}$ and $U_{H_{P}}(t)=\frac{j A_{t}^{j}}{H_{P, t}}$.

Similarly to deposits, the first order condition for bonds shows that patient households want to equate the interest income from bonds to the marginal cost of forgone consumption from higher bond holdings. 


\section{Impatient households}

\section{FOC for labour:}

$$
\frac{U_{C_{I}}(t)}{\left(1+\tau_{t}^{C}\right)}\left(1-\tau_{t}^{W}\right) W_{I, t}+U_{N_{I}}(t)=0
$$

similarly to patient households, it shows that impatient households want to equate the after-tax returns from labour to the marginal rate of substitution between consumption and labour.

\section{FOC for housing demand:}

$$
\begin{aligned}
0 & =\beta_{I} E_{t}\left\{\frac{U_{C_{I}}(t+1)}{\left(1+\tau_{t+1}^{C}\right)}\left(1-\tau_{t}^{H}\right) q_{t+1}\right\}+U_{H_{I}}(t)-q_{t} \frac{U_{C_{I}}(t)}{\left(1+\tau_{t}^{C}\right)}+ \\
& +\lambda_{I, t}\left(1-\rho_{I}\right) A_{t}^{M} m_{I}\left(1-\tau_{t}^{H}\right) E_{t}\left\{\frac{q_{t+1}}{R_{I, t}}\right\} \frac{U_{C_{I}}(t)}{\left(1+\tau_{t}^{C}\right)}
\end{aligned}
$$

shows that impatient households want to equate the expected after-tax return from housing to the marginal utility gain from the additional housing and the marginal cost of obtaining a higher stock of housing. The additional term $\lambda_{I, t}$ measures the credit constraint faced by the impatient households and introduces an intertemporal wedge to the housing demand.

\section{FOC for loans:}

$$
\beta_{I} E_{t}\left\{\left(R_{I, t}-\rho_{I} \lambda_{I, t+1}\right) \frac{U_{C_{I}}(t+1)}{\left(1+\tau_{t+1}^{C}\right)}\right\}=\left(1-\lambda_{I, t}\right) \frac{U_{C_{I}}(t)}{\left(1+\tau_{t}^{C}\right)}
$$

where $U_{C_{I}}(t)=\frac{1}{C_{I, t}}, U_{N_{I}}(t)=-\frac{\eta}{1-N_{I, t}}$ and $U_{H_{I}}(t)=\frac{j A_{t}^{j}}{H_{I, t}}$.

The first order condition for loans shows that impatient households want to equate the interest payment on loans and the marginal cost of future forgone consumption to the marginal gain of current consumption. The lagrange multiplier associated with the borrowing constraint of the impatient households, $\lambda_{I, t}$, introduces an intertemporal wedge again to loans demand as in the first order condition for housing demand.

\section{Banks}

FOC for deposits:

$$
\left(1-\lambda_{B, t}\right) \frac{U_{C_{B}}(t)}{\left(1+\tau_{t}^{C}\right)}=\beta_{B} E_{t}\left\{\left(R_{P, t}-\rho_{B} \lambda_{B, t+1}\right) \frac{U_{C_{B}}(t+1)}{\left(1+\tau_{t+1}^{C}\right)}\right\}
$$


shows that banks want to equate the pay-off from an additional consumption today due to higher deposits to the cost of paying back the interest on deposits and the marginal cost of lower future consumption. $\lambda_{B, t}$ measures the credit constraint faced by banks and introduces an intertemporal wedge to the demand for deposits.

FOC for loans to impatient households:

$$
\begin{aligned}
& \left(1-\left(\gamma\left(1-\rho_{B}\right)+\rho_{B}\right)-\lambda_{B, t}\right) \frac{U_{C_{B}}(t)}{\left(1+\tau_{t}^{C}\right)} \\
& =\beta_{B} E_{t}\left\{\left(R_{I, t}-\rho_{B} \lambda_{B, t+1}\right) \frac{U_{C_{B}}(t+1)}{\left(1+\tau_{t+1}^{C}\right)}\right\}
\end{aligned}
$$

FOC for loans to entrepreneurs:

$$
\begin{aligned}
& \left(1-\left(\gamma\left(1-\rho_{B}\right)+\rho_{B}\right)-\lambda_{B, t}\right) \frac{U_{C_{B}}(t)}{\left(1+\tau_{t}^{C}\right)} \\
& =\beta_{B} E_{t}\left\{\left(R_{E, t+1}-\rho_{B} \lambda_{B, t+1}\right) \frac{U_{C_{B}}(t+1)}{\left(1+\tau_{t+1}^{C}\right)}\right\}
\end{aligned}
$$

where $U_{C_{B}}(t)=\frac{1}{C_{B, t}}$ and the variable $\lambda_{B, t}$ is the lagrange multiplier associated with the borrowing constraint.

In both conditions above banks want to equate the additional consumption today via lower loans to the marginal utility cost of tighter borrowing constraint. $\lambda_{B, t}$ measures the credit constraint faced by banks and introduces again an intertemporal wedge to the supply of loans.

\section{Entrepreneurs}

\section{FOC for loans:}

$$
\left(1-\lambda_{E, t}\right) \frac{U_{C_{E}}(t)}{\left(1+\tau_{t}^{C}\right)}=\beta_{E} E_{t}\left\{\left(R_{E, t}-\rho_{E} \lambda_{E, t+1}\right) \frac{U_{C_{E}}(t+1)}{\left(1+\tau_{t+1}^{C}\right)}\right\}
$$

The first order condition for loans shows that entrepreneurs the interest payment on loans and the marginal cost of future forgone consumption to the marginal gain of current consumption. The lagrange multiplier associated with the borrowing constraint of the entrepreneurs, $\lambda_{E, t}$, introduces an intertemporal wedge again to the demand for loans.

FOC for real estate:

$$
\begin{aligned}
& \left(q_{t}-\lambda_{E, t}\left(1-\rho_{E}\right) A_{t}^{M} m_{E H} E_{t}\left\{\left(1-\tau_{t}^{H}\right) \frac{q_{t+1}}{R_{E, t+1}}\right\}\right) \frac{U_{C_{E}}(t)}{\left(1+\tau_{t}^{C}\right)} \\
& =\beta_{E} E_{t}\left\{q_{t+1}\left(1+R_{V, t+1}\right) \frac{U_{C_{E}}(t+1)}{\left(1+\tau_{t+1}^{C}\right)}\right\}
\end{aligned}
$$


where $U_{C_{E}}(t)=\frac{1}{C_{E, t}}$ and the variable $\lambda_{E, t}$ is the lagrange multiplier associated with the borrowing constraint.

The condition above shows that entrepreneurs equate the expected aftertax return from real estate to the marginal cost of obtaining a higher stock of real estate. The additional term $\lambda_{E, t}$ measures the credit constraint faced by the entrepreneurs and introduces an intertemporal wedge to their real estate demand.

Additionally, we combine the above conditions with the following standard first order conditions of the production process were marginal return equals marginal cost of the factors taking into account the credit constraint of the entrepreneur:

$$
\begin{gathered}
\nu Y_{t}=R_{v, t} q_{t} H_{E, t-1} \\
(1-\nu)(1-\sigma) \frac{Y_{t}}{N_{P, t}}=W_{P, t}\left(1+\left(1-\rho_{E}\right) m_{E N} \lambda_{E, t}\right) \\
(1-\nu) \sigma \frac{Y_{t}}{N_{I, t}}=W_{I, t}\left(1+\left(1-\rho_{E}\right) m_{E N} \lambda_{E, t}\right)
\end{gathered}
$$



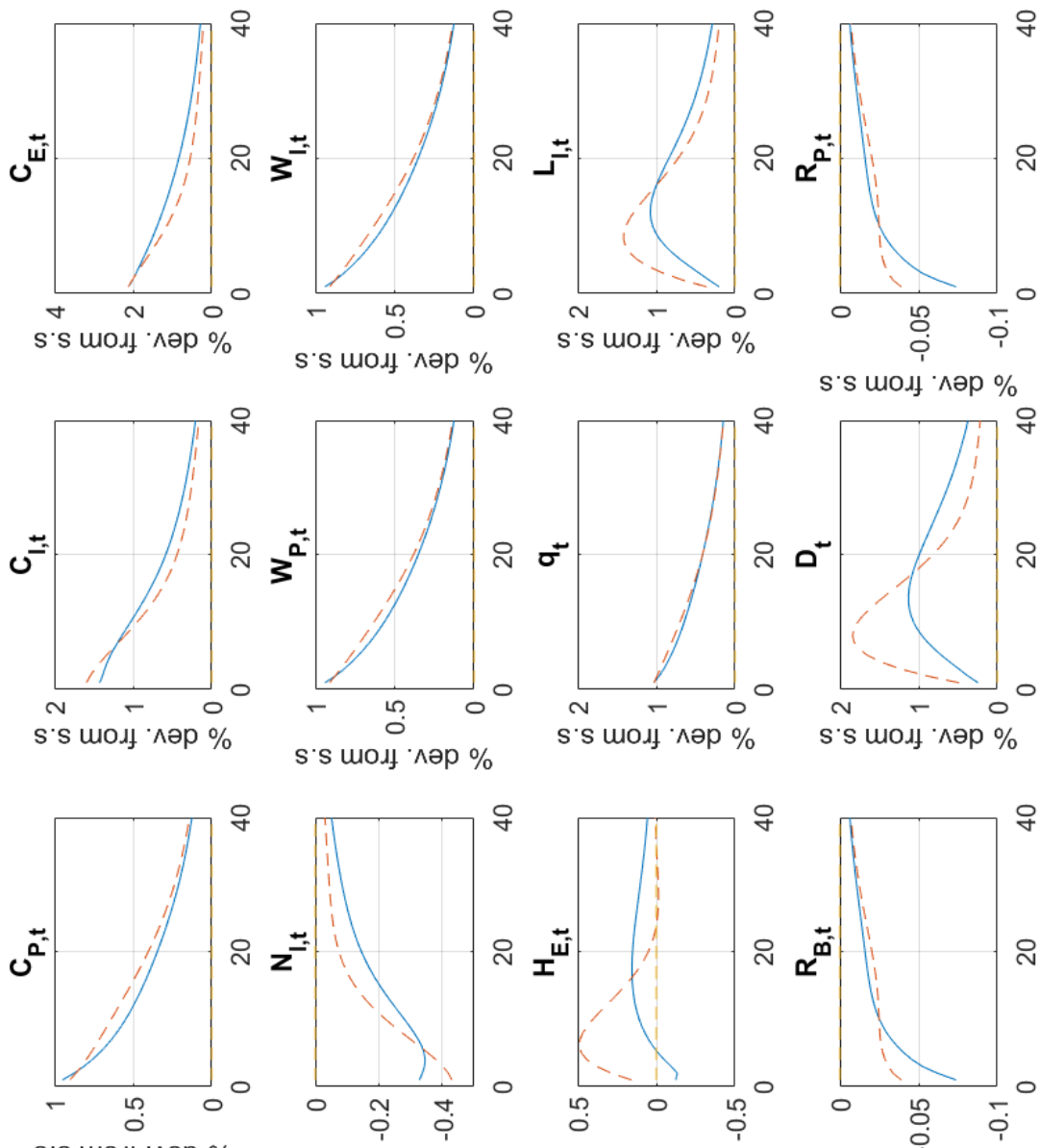

s's modf '^әр \%

s's moג '

s's moג '^әр \%

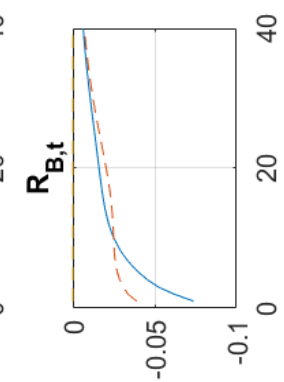

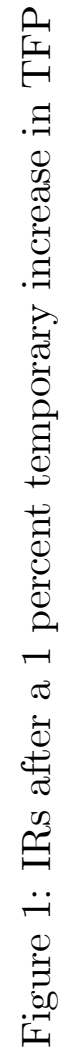
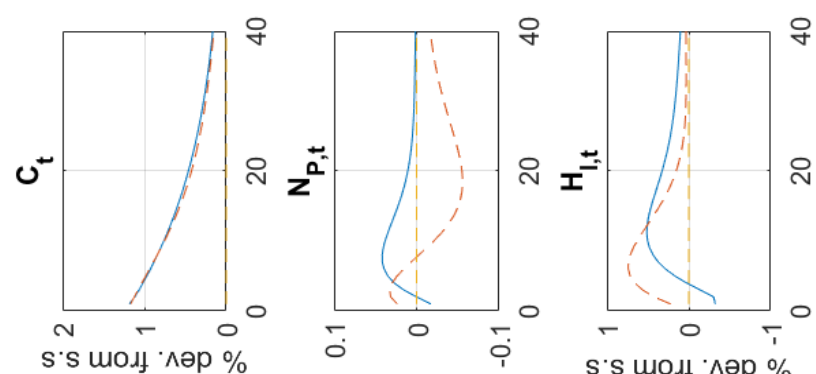

s's moג '

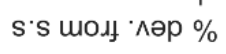

s's modf '^әр \%

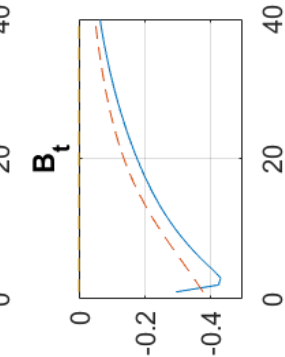

s's moגf ' $ә р$ \%

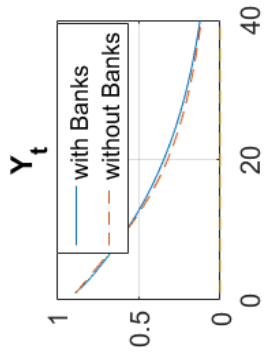

's's moג! '^әр \%
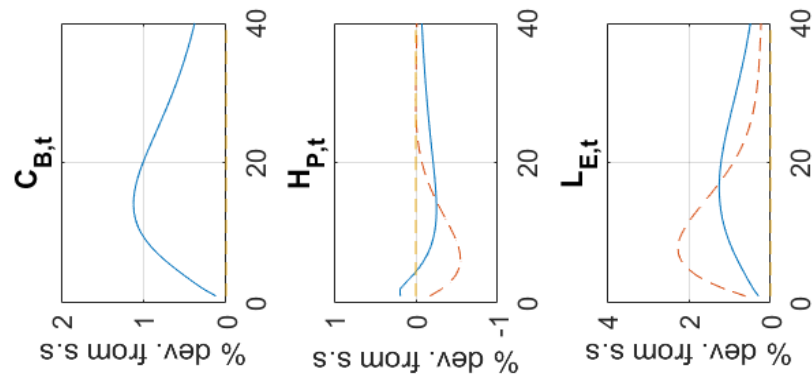

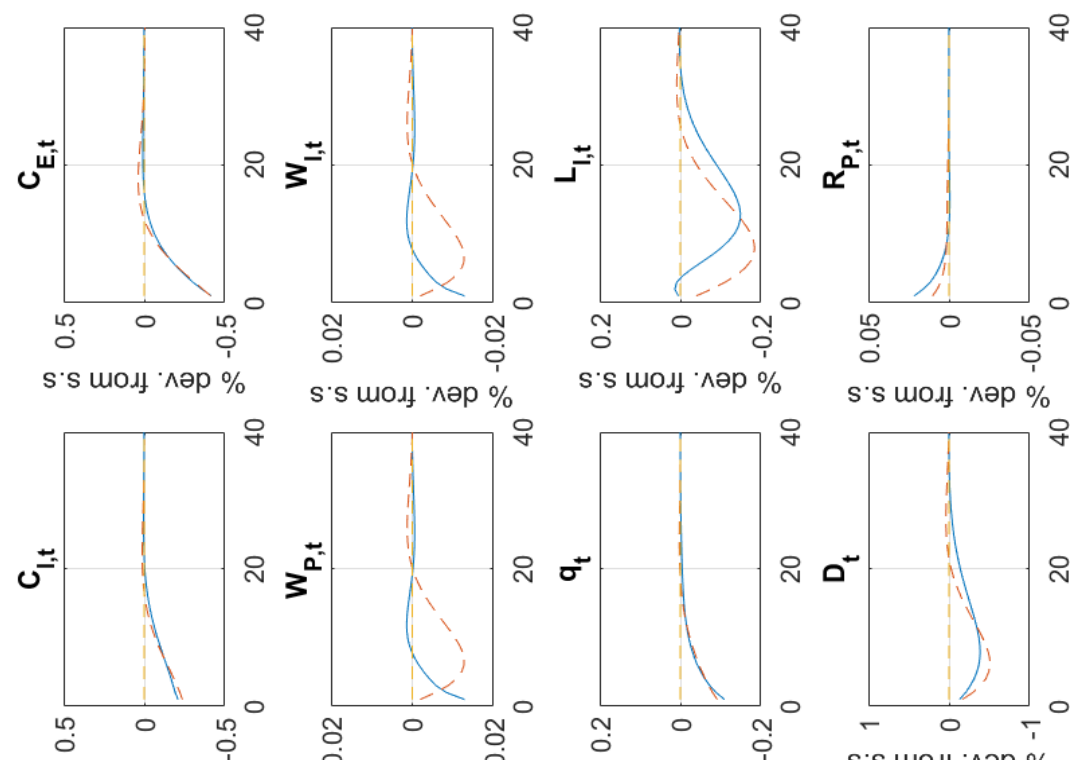

s's moגf '^әр \%

s's moㄹ ' $ә$ әр \%

s's modf ' $ә ә р \%$
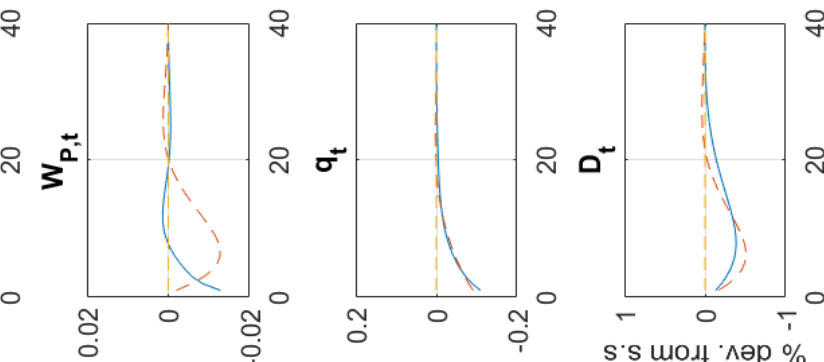

 s's moдf '
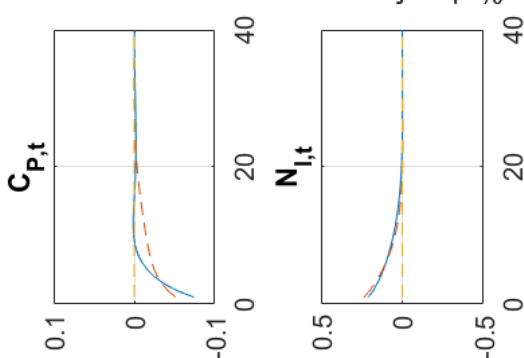

s's moגf ' ^әр \%
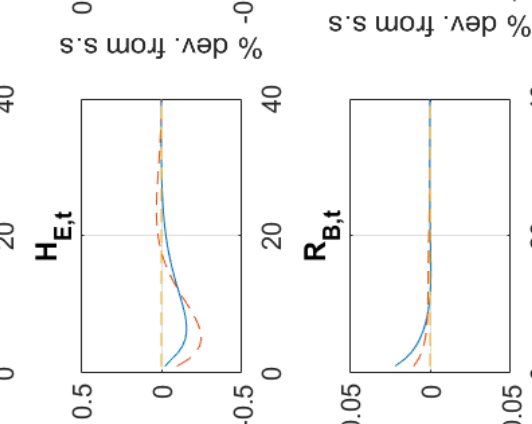

요

ㅇ

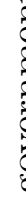

s's mол '
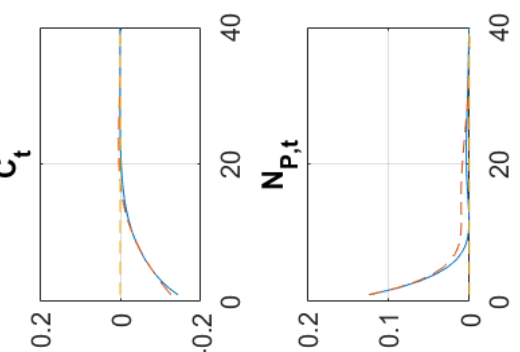

s's moג '^әр \%

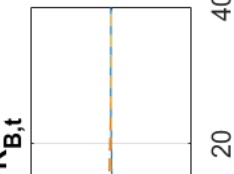

ㅇ

.$\exists$

s's moц '^әр \% s's moג ' $ә ә р \%$
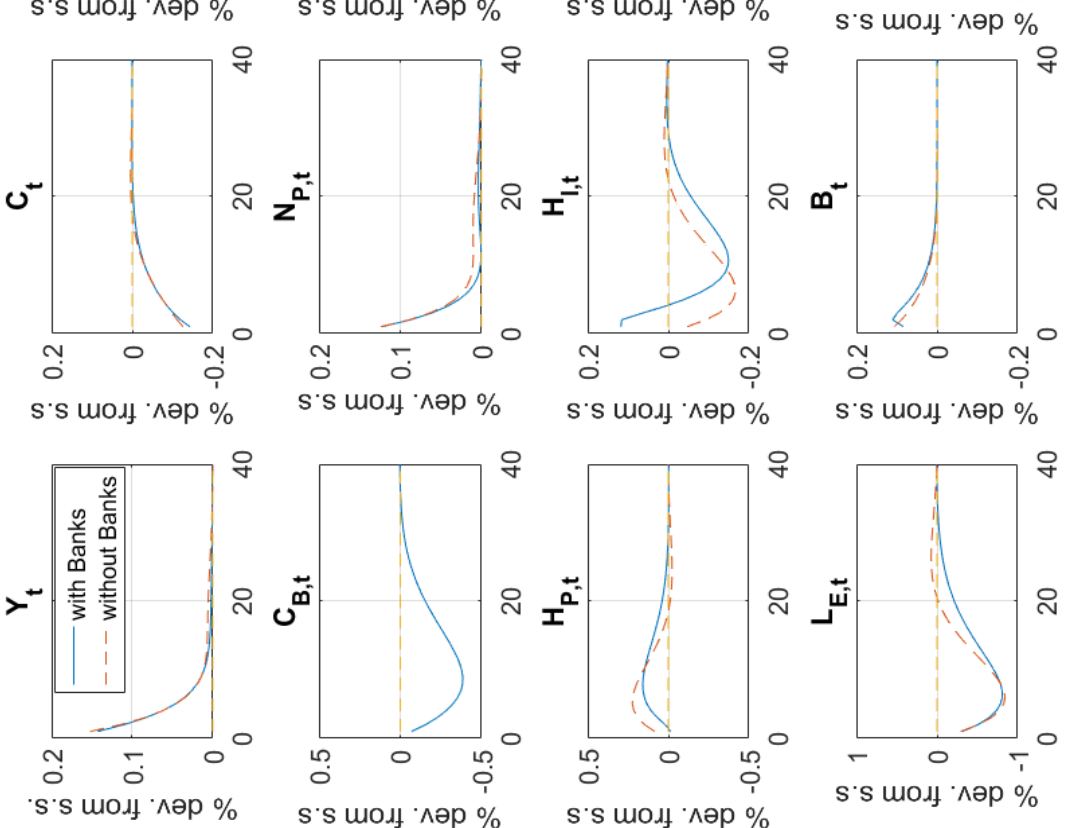

s's moגf ' ^әр \%

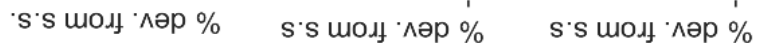



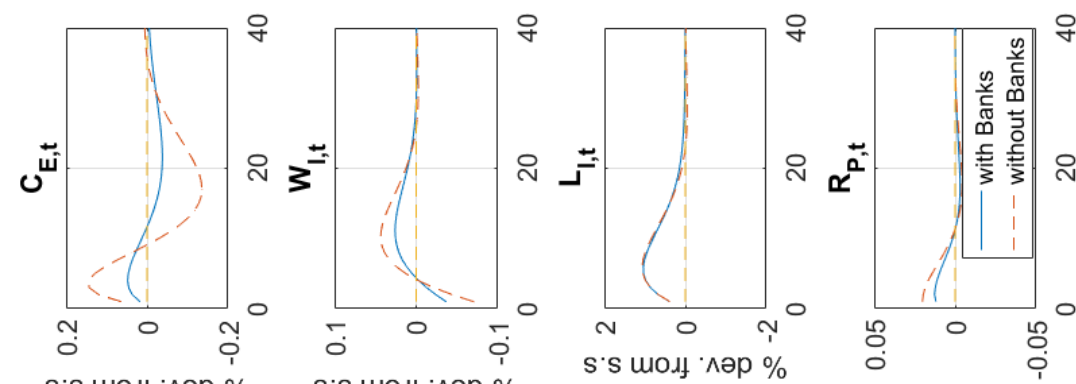

s's molf 'sәр \% s's molf 'sәp \%
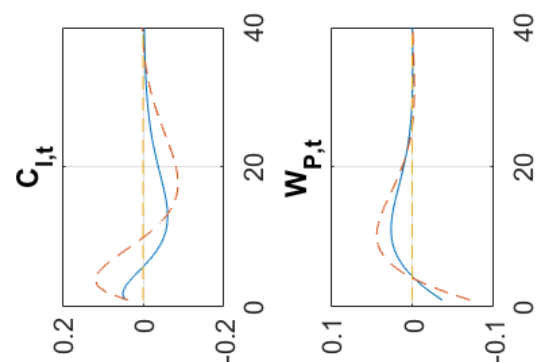

s's modf 'sәр \%

s's moג ‘ ^әр \%

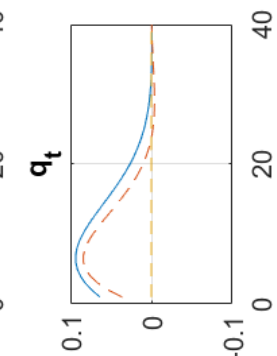

우

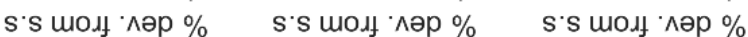
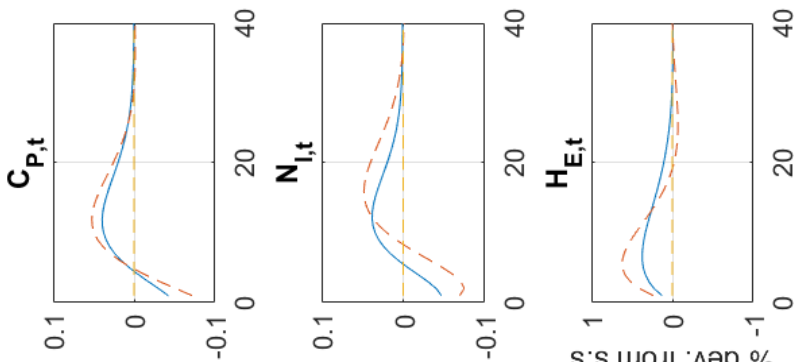

s's moגf '^әр \% S's moגf '
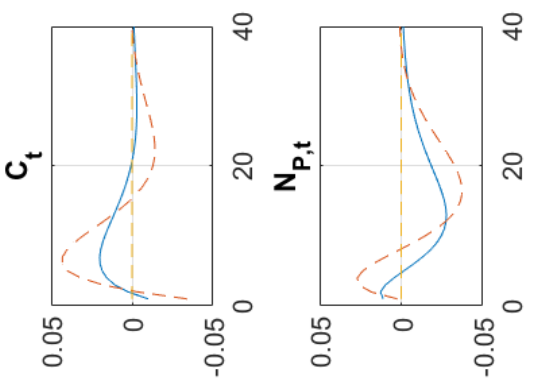

q

s's moגf '^әр \%

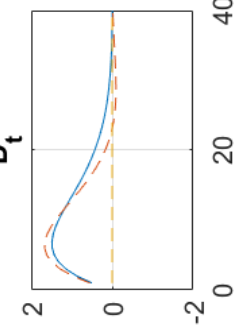

ล

s's molf '^әр \%

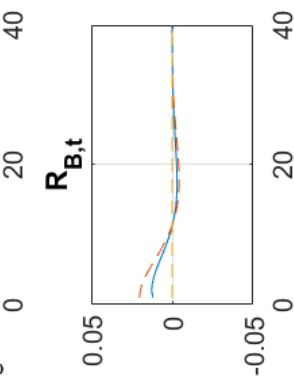

s's moㅅ ^ар \%

웅

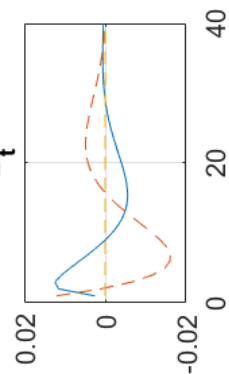

s's mof '^әр \%

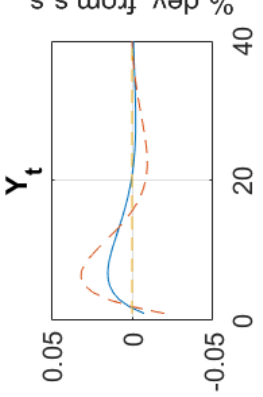

s's moגf ' $\wedge$ әр \%
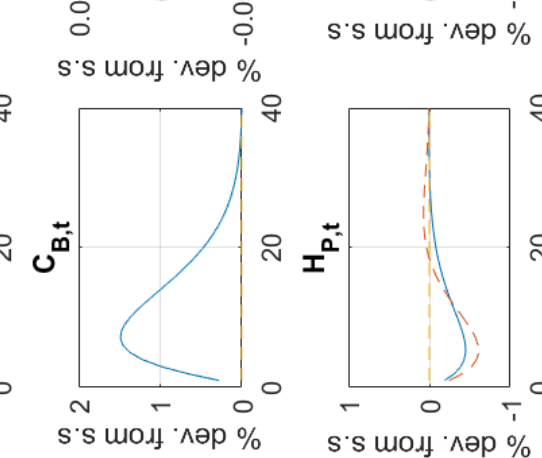

ㅇ

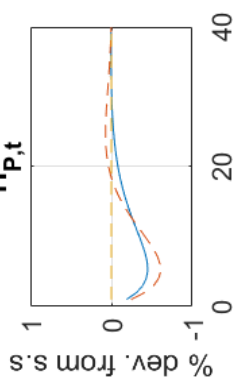

웅

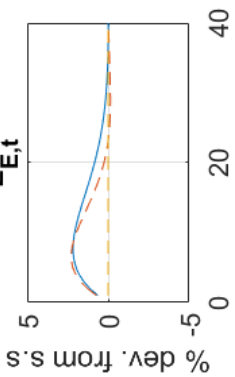

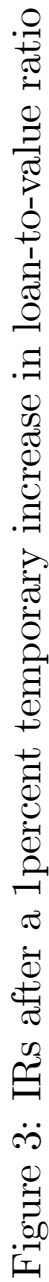

's's moגf '^әр \%

s's moג ' 

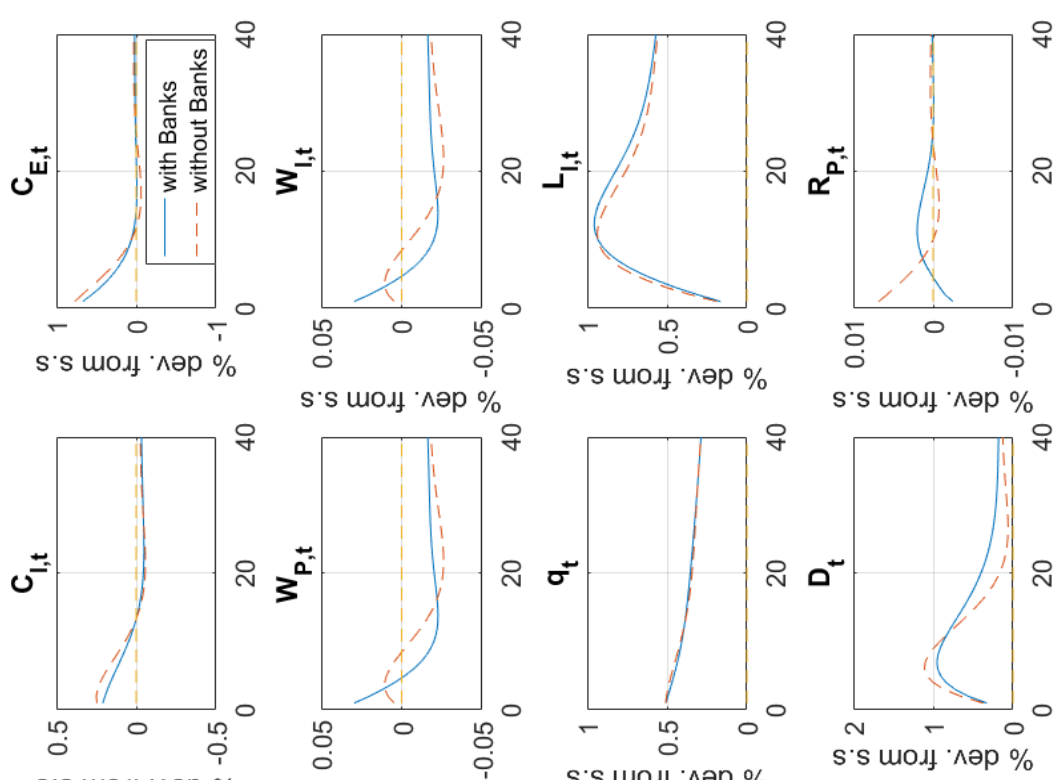

우

s's mof '^әр \% s's moג '
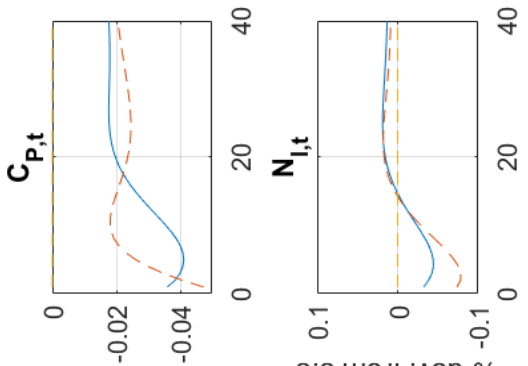

s's moגf '^әр \%

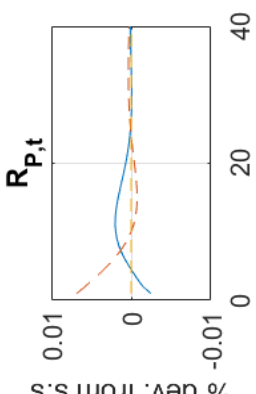

s's moגf '^әр \%
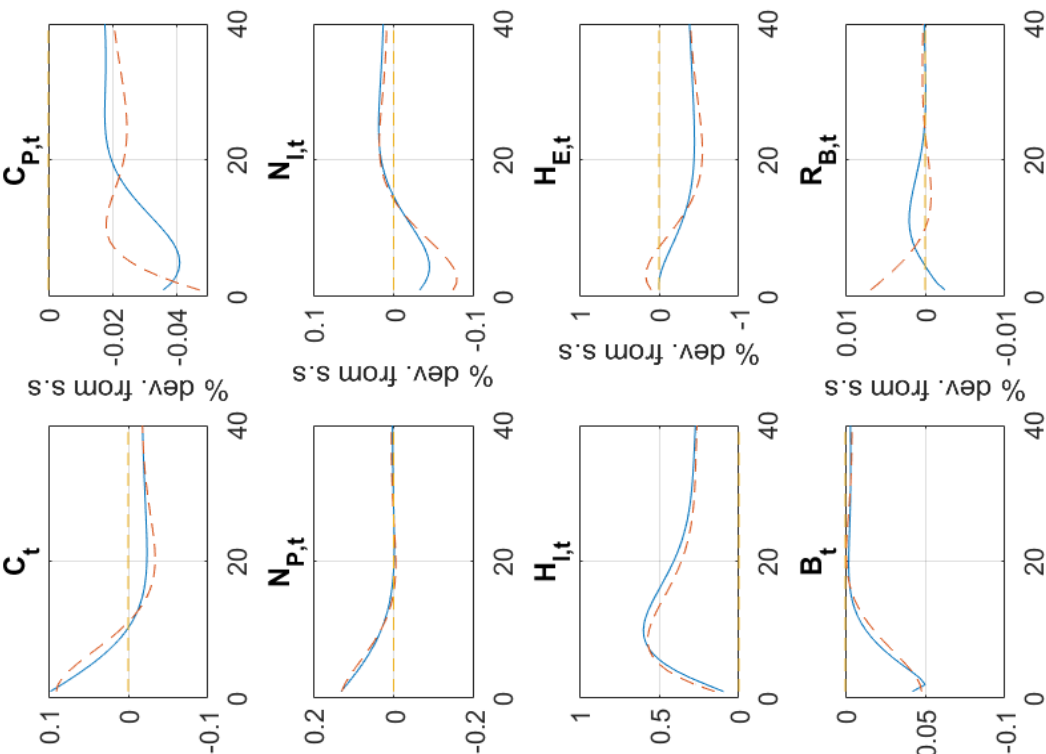

s's moג ' $ә$ әр \%

s's moגt ^ ^әр \%

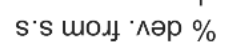

s's moגf ' ^әр \%

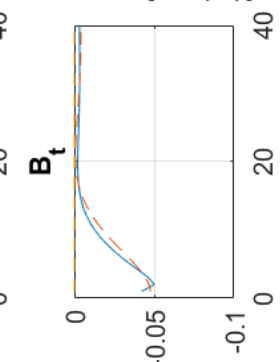

s's moג' ^әр \%
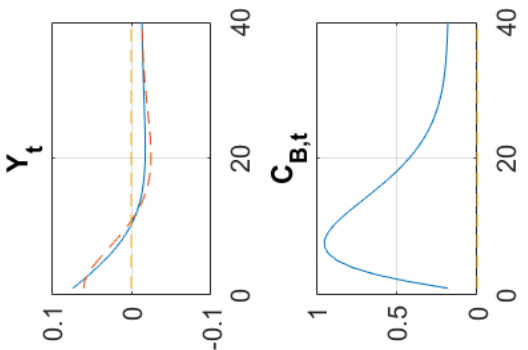

's's moגf ' ^әр \%

s's mo사 '^әр \%
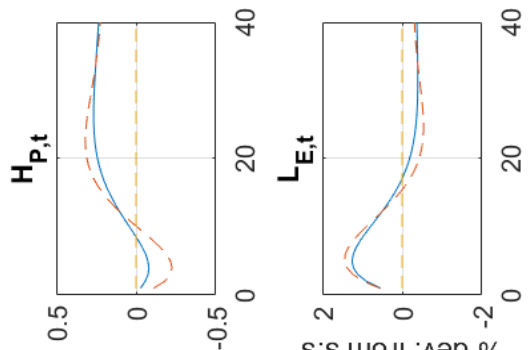

s's modf ' ^әр \%

s's moц ' ^әр \% 

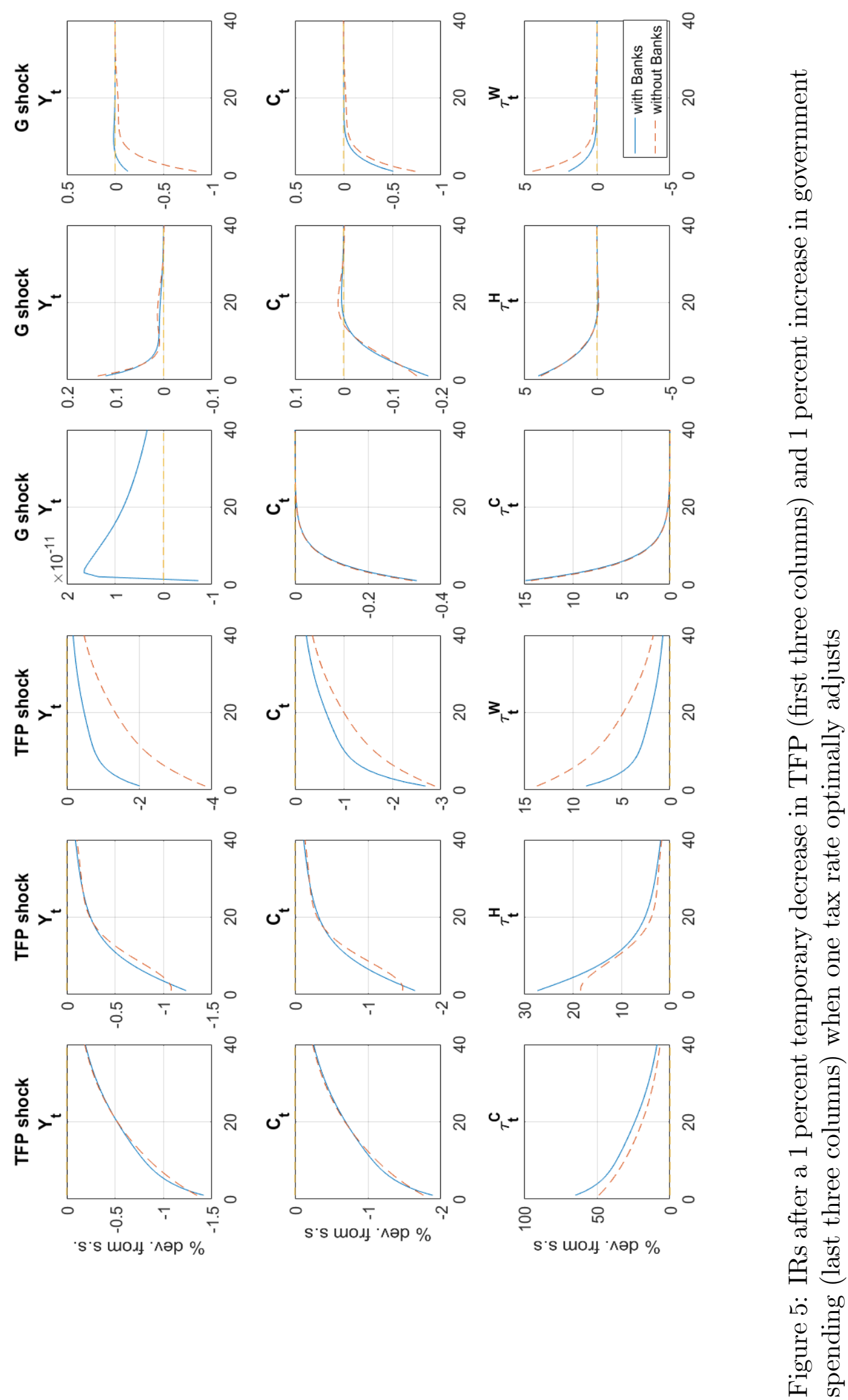

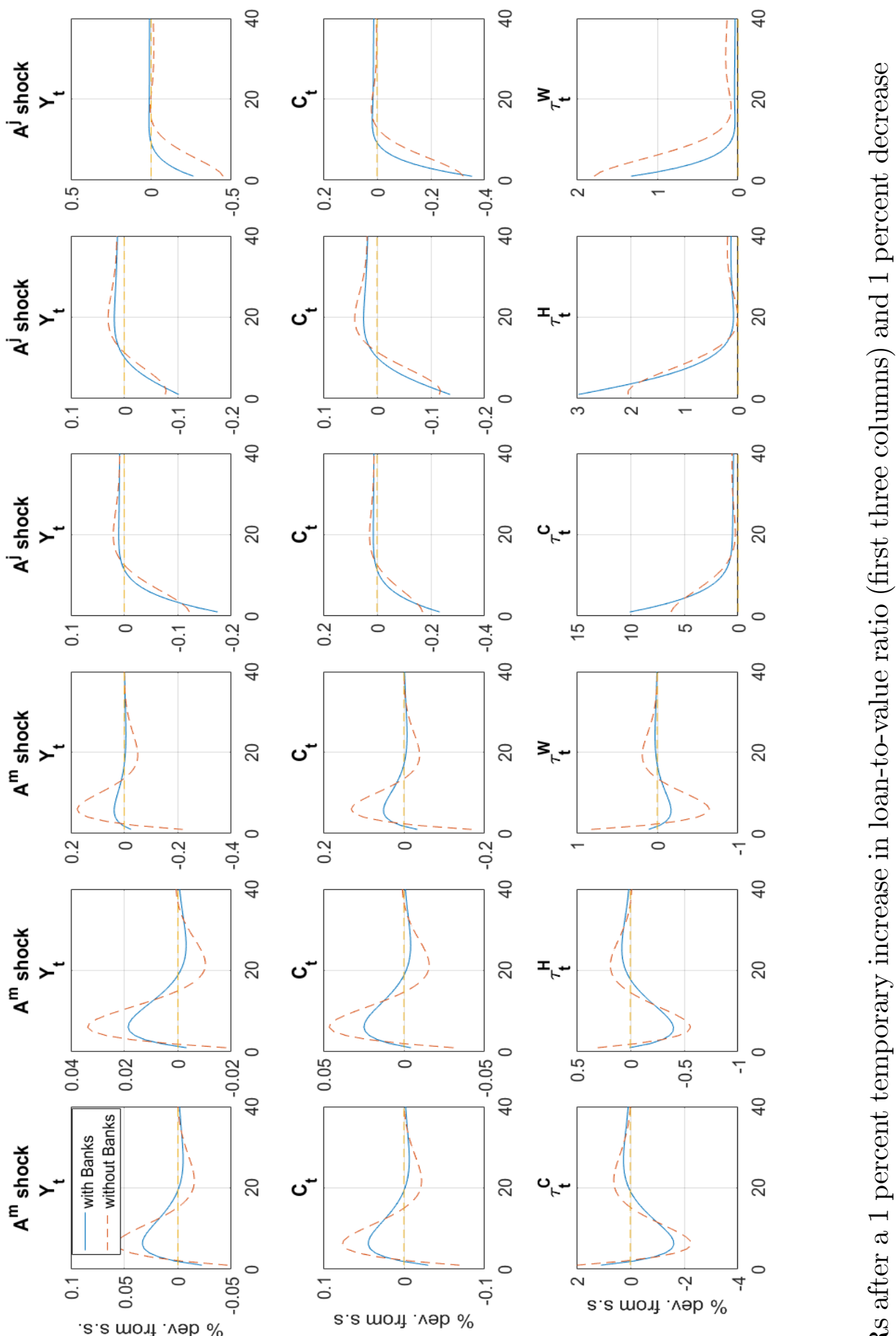

.



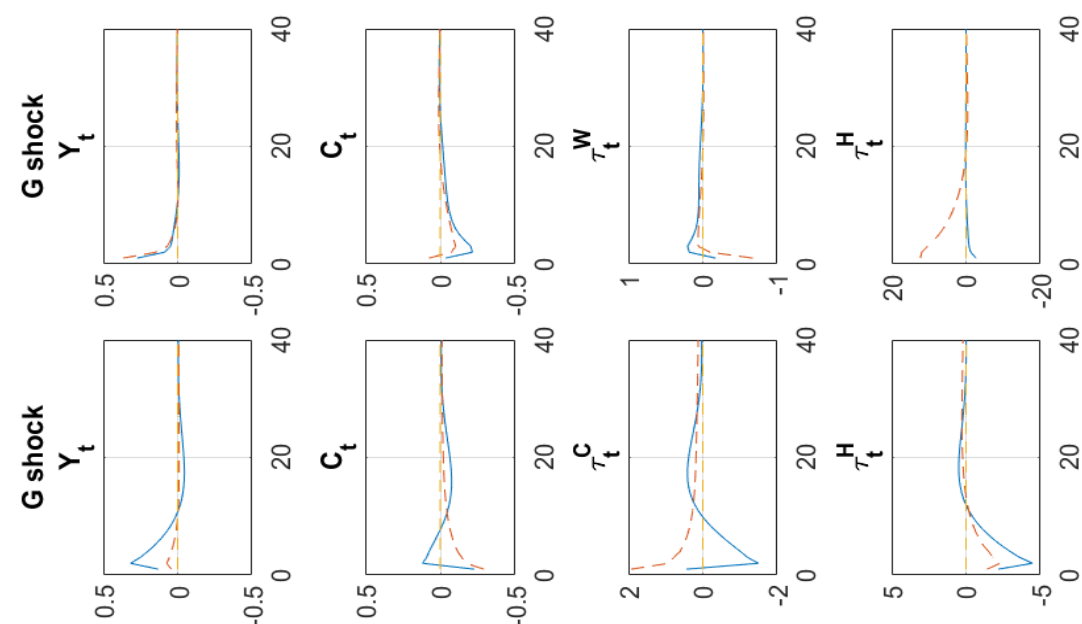

2

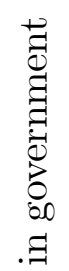
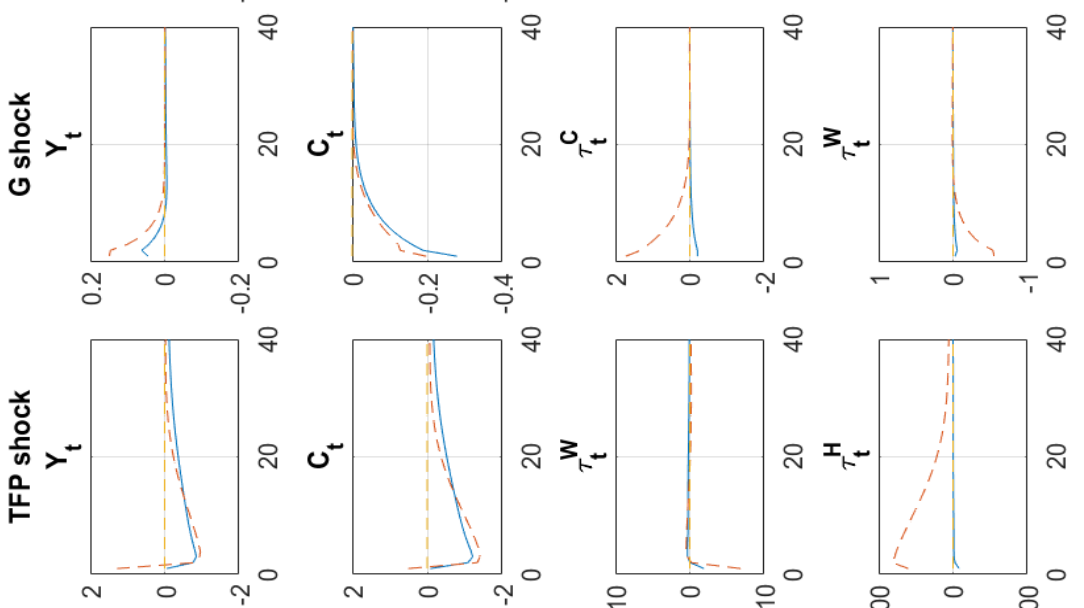

웅
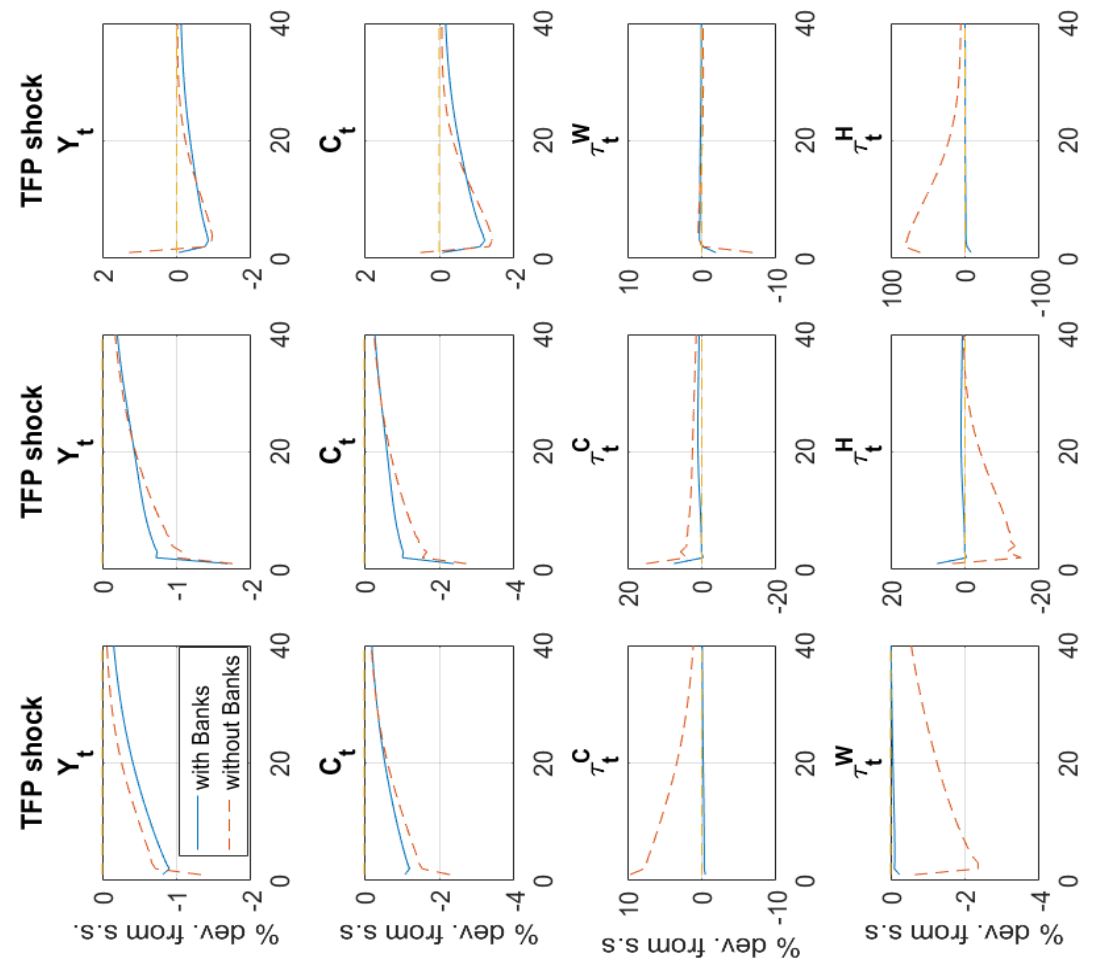

q

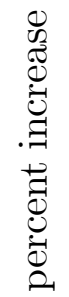

ت્

8

壳

进

릴

H

. ठै

)

.

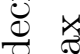

㻤草

용

छี

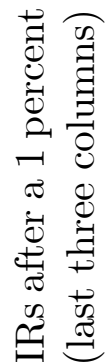

$\ddot{\sim} \infty$

ㅋㅋㅋ

点 

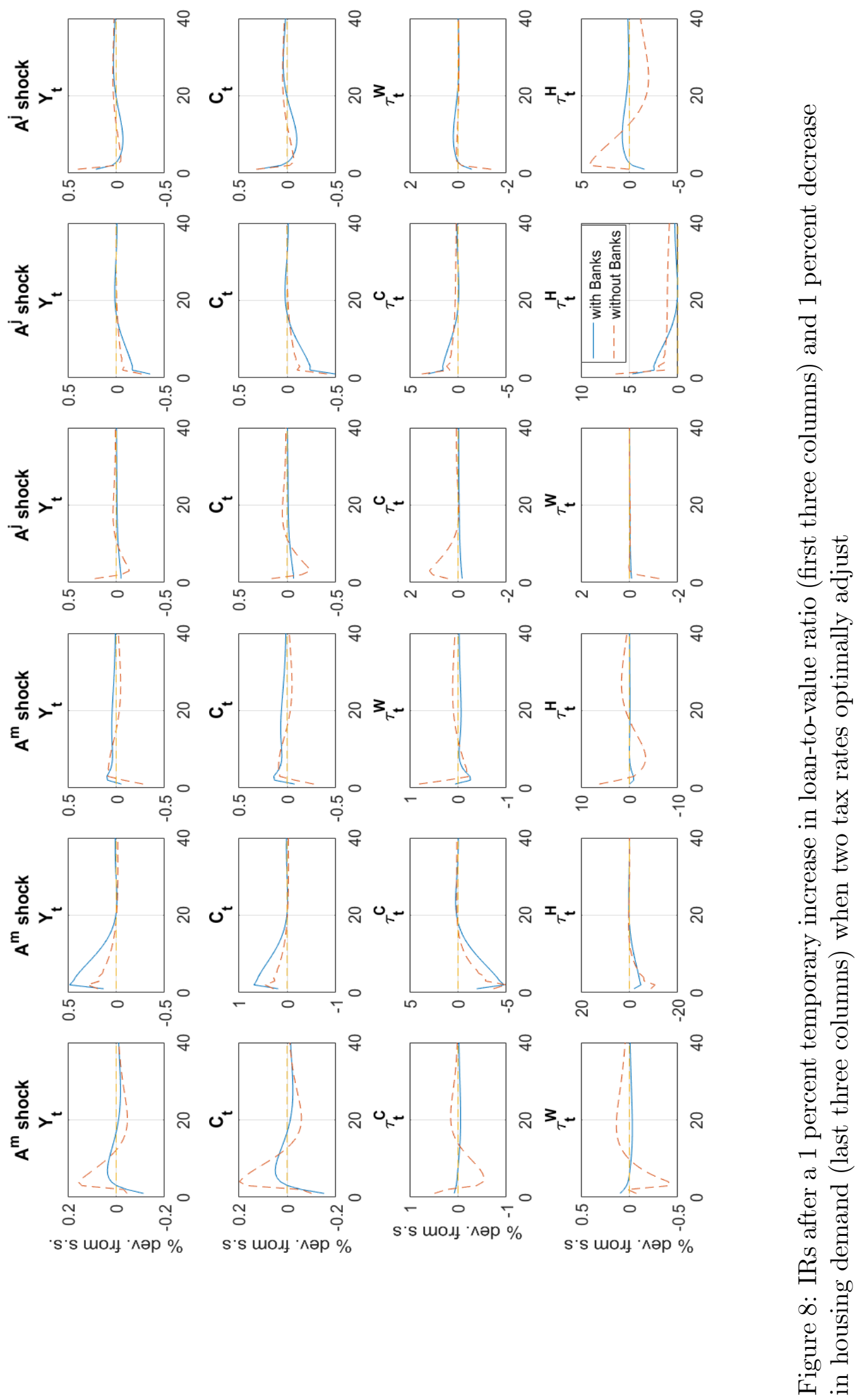